\title{
Aptian carbonate platform development in the Southern Iberian Palaeomargin (Prebetic of Alicante, SE Spain) ${ }^{\text {is }}$
}

\author{
Peter W. Skelton ${ }^{1, *}$, José Manuel Castro ${ }^{2}$ and Pedro Alejandro Ruiz-Ortiz ${ }^{2}$ \\ 1 The Open University, Milton Keynes, UK \\ 2 Centre for Advanced Studies in Earth Sciences, CEACTierra, Department of Geology, Universidad de Jaén, Jaén, Spain
}

Received: 10 August 2018 / Accepted: 18 December 2018

\begin{abstract}
The Aptian stratigraphic record of the Alicante region consists of: a rudist and coral-rich carbonate platform of earliest Aptian age (Llopis Formation), with a discontinuous siliciclastic member at its top; followed by late Early, to Late Aptian hemipelagic marls and marlstones (Almadich Formation); and then by renewed carbonate platform development of Late Aptian to earliest Albian age (Seguilí Formation). In the Llopis Formation, SW-dipping, massive clinoform beds of bioclastic debris are succeeded by flat-lying platform-top beds. The latter show a cyclically regressive stacking of biofacies, with rudist-dominated floatstone in their lower parts passing upwards to finer-grained, more sparsely fossiliferous bed tops with burrow mottling. Caprinid rudists, with originally almost wholly aragonitic shells, dominate the external platform-top facies, while more internal facies contain a mix of monopleurid, polyconitid and requieniid rudists, all with relatively slightly thicker development of the calcitic outer shell layer, together with caprinids. Biostratigraphic and carbon-isotope data link the termination of the Llopis platform with the onset of OAE1a. The carbonate platform of the Seguilí Formation again contains tabular platform-top beds showing repeated cyclic regression, with dense rudist and/or chondrodont floatstones overlain by sparser floatstones with wackestone matrix and secondarily filled burrows. But caprinids are now absent, while requieniids and polyconitids, some of large size, as well as radiolitids, all with thickened calcitic outer shell layers, accompany the tubular monopleurid, Mathesia, together with a greater development of Chondrodonta biofacies. The same overall pattern of biotic turnover from the Early, to the Late Aptian is confirmed in other parts of Iberia and contiguous regions. Moreover, Iberian platforms of late Early Aptian age outside the present study area reveal a transitional phase with an increasing proportion of polyconitids in the outer platform-top to upper slope facies at the expense of caprinids. The siliciclastic influx at the top of the Llopis Formation implies a climatic shift from arid, to relatively more humid/pluvial conditions through the midEarly Aptian, as seen in several other Iberian sections. This climatic change was probably forced by the intensified greenhouse conditions at the onset of OAE1a. By contrast with these Iberian platforms, caprinids continued to dominate the outer platform-top zones of some central to southern Tethyan platforms until the close of the Early Aptian. This broad palaeolatitudinal differentiation of rudist associations within the Tethyan belt implies a climatic influence, whether exerted through thermal modulation of seawater $\mathrm{pH}$ and/or aragonite saturation, variation in nutrient flux, or any combination of these.
\end{abstract}

Keywords: Aptian / carbonate platforms / Prebetic Zone / palaeoecology / rudist coral formations / OAE1a

\begin{abstract}
Résumé - Développement des plates-formes carbonatées dans l'Aptien de la marge continentale sud-Ibérique (Prébétique d'Alicante, SE d'Espagne). L'enregistrement stratigraphique de l'Aptien de la région d'Alicante comprend successivement une plate-forme carbonatée à rudistes et coraux abondants dans l'Aptien basal (Formation de Llopis), un membre silicoclastique discontinu à son sommet, des marnes hémipélagiques jusqu'à l'Aptien supérieur (formation d'Almadich), puis via un développement renouvelé, une plate-forme carbonatée datée de l'Aptien tardif à Albien basal (Formation de Seguilí). Dans la formation de Llopis, des clinoformes massifs à débris bioclastiques, inclinés vers le SW, sont surmontés par des lits horizontaux au toit de la plate-forme. Ces derniers montrent un empilement de biofaciès cycliquement régressifs, comprenant des floatstones dominés par les rudistes dans leur partie inférieure, puis enregistrent
\end{abstract}

\footnotetext{
خ Cet article est écrit suite à une séance spécialisée de la SGF en l'honneur d'Hubert Arnaud («Journées Hubert Arnaud»).

* Corresponding author: pwskelto@waitrose.com
} 
vers le haut une diminution de la granulométrie et des macrofossiles et enfin, des marbrures de terriers au sommet. Les rudistes caprinidés, aux coquilles à l'origine presque entièrement aragonitiques, dominent le faciès externe du toit de la plate-forme, tandis que les faciès internes contiennent un mélange de rudistes monopleuridés, polyconitidés et requiéniidés. L'ensemble de ces rudistes montrent un développement relativement plus épais de la couche externe calcitique par rapport à celle des caprinidés. Les données biostratigraphiques et isotopiques établissent un lien entre la fin de la plate-forme Llopis et l'apparition de l'OAE 1a. La plate-forme carbonatée de la formation de Seguilí comprend à nouveau des lits tabulaires à son sommet, correspondant à des régressions cycliques répétées, avec des floatstones denses à rudistes et/ou à chondrodontes, recouverts par des floatstones plus clairsemés à matrice wackestone présentant des terriers secondairement remplis. Il est à noter l'absence des caprinidés. Les requiéniidés et les polyconitidés dont certains sont de grande taille, ainsi que les radiolitidés, tous dotés d'épaisses couches superficielles de calcite, accompagnent le monopleuridé tubulaire Mathesia, ainsi qu'un développement plus important des biofaciès à Chondrodonta. Le même schéma général de renouvellement biotique du début à la fin de l'Aptien est confirmé dans d'autres secteurs de la péninsule ibérique et des régions contiguës. De plus, les plates-formes ibériques du sommet de l'Aptien inférieur, situées en dehors de la zone d'étude, révèlent une phase de transition caractérisée par une proportion croissante de polyconitidés dans le faciès extérieur de la plate-forme et au sommet de la pente supérieure, aux dépens des caprinidés. L'afflux siliciclastique au sommet de la formation de Llopis implique un passage climatique des conditions arides à des conditions relativement plus humides/pluviales à la partie moyenne de l'Aptien inférieur, comme dans plusieurs autres sections ibériques. Ce changement climatique a probablement été forcé par l'intensification des conditions de serre au début de l'OAE1a. Contrairement à ces plates-formes ibériques, les caprinidés ont continué à dominer les zones les plus à l'extérieur des plates-formes de certaines plates-formes du centre au sud de Téthys jusqu'à la fin de l'Aptien inférieur. Cette large différenciation paléolatitudinale d'associations à rudistes au sein de la ceinture téthysienne implique une influence climatique, qu'elle soit exercée par modulation thermique du $\mathrm{pH}$ de l'eau de mer et/ou de la saturation en aragonite, soit par la variation du flux d'éléments nutritifs, ou soit par une combinaison de ces facteurs.

Mots clés : Aptien / plates-formes carbonatées / Zone Prébétique / paléoécologie / formations à rudistes et coraux / OAE1a

\section{Introduction}

Within the broad context of interest in the greenhouse world of the Cretaceous, considerable attention has been paid to the remarkable oceanic, climatic and biotic changes that occurred during the Aptian, including the episodic growth and demise of Tethyan carbonate platforms. Naturally, there has also been much discussion concerning controls on these changes, particularly the (still controversial) idea of a possible causal linkage with perturbations of the global carbon cycle. Hence, there is an ongoing need for high resolution stratigraphical investigations of comparatively complete basin to platform sections, to determine as precisely as possible the relative timing and palaeogeographical record of events in order to constrain or test explanatory models (Skelton et al., 2012; Naafs et al., 2016). Such is the basis of Spanish Government research project CGL2014-55274-P, "El Aptiense del Prebético: Cambios ambientales, bióticos y factores de control", involving detailed analysis of newly drilled cores in a hemipelagic section (Cau, Alicante Province) and biostratigraphical and palaeoecological logging of adjacent carbonate platform successions. This paper focuses on documenting changes in the macrobiotic biofacies constitution of the carbonate platforms, especially with respect to their dominant macrofossil constituent, the rudist bivalves.

The two main platform developments in the study area chronostratigraphically encompass the early part of the Early Aptian (lower Bedoulian middle to upper Llopis Formation) and the late Late Aptian to earliest Albian (upper Gargasian to lower Albian Seguilí Formation). In a final discussion section, we also review the macrobiotic constitution of selected platform developments outside the study area that represent the intervening late Early Aptian interval elsewhere in Spain, in order to characterize the pattern of faunal turnover in Iberian platforms throughout the Aptian. Finally, we consider possible controls on these biofacies changes.

\subsection{Geological setting}

The External Zones of the Betic Cordillera (Fig. 1a) are made of sedimentary units deposited on the Southern Iberian Palaeomargin (SIP) during the Alpine tectonic cycle (Triassic to early Miocene) (García-Hernández et al., 1980; Vera, 2001, 2004). North of the Cordillera, Prebetic para-autochthonous units deposited on the SIP were overthrust by Subbetic allochthonous units that had accumulated in the pelagic domains to the south.

The initiation of seafloor spreading in the North Atlantic, which started very early in the Cretaceous, led to a decrease in the sinistral movement between Iberia and Africa that had prevailed during part of the Jurassic (Ziegler, 1988), and to a phase of rapid anti-clockwise rotation of Iberia relative to Europe that would culminate in seafloor spreading in the Bay of Biscay from middle Aptian times onwards (Olivet, 1996; Vergès and García-Senz, 2001). A more recent study (Tugend et al., 2015) suggests an alternative model to the rapid anticlockwise rotation, consisting in a north-south divergence between Europe and Iberia, leading to a polyphase propagation of the extensional regime affecting both the Atlantic Ocean and the Alpine Tethys systems. In whichever geodynamic 


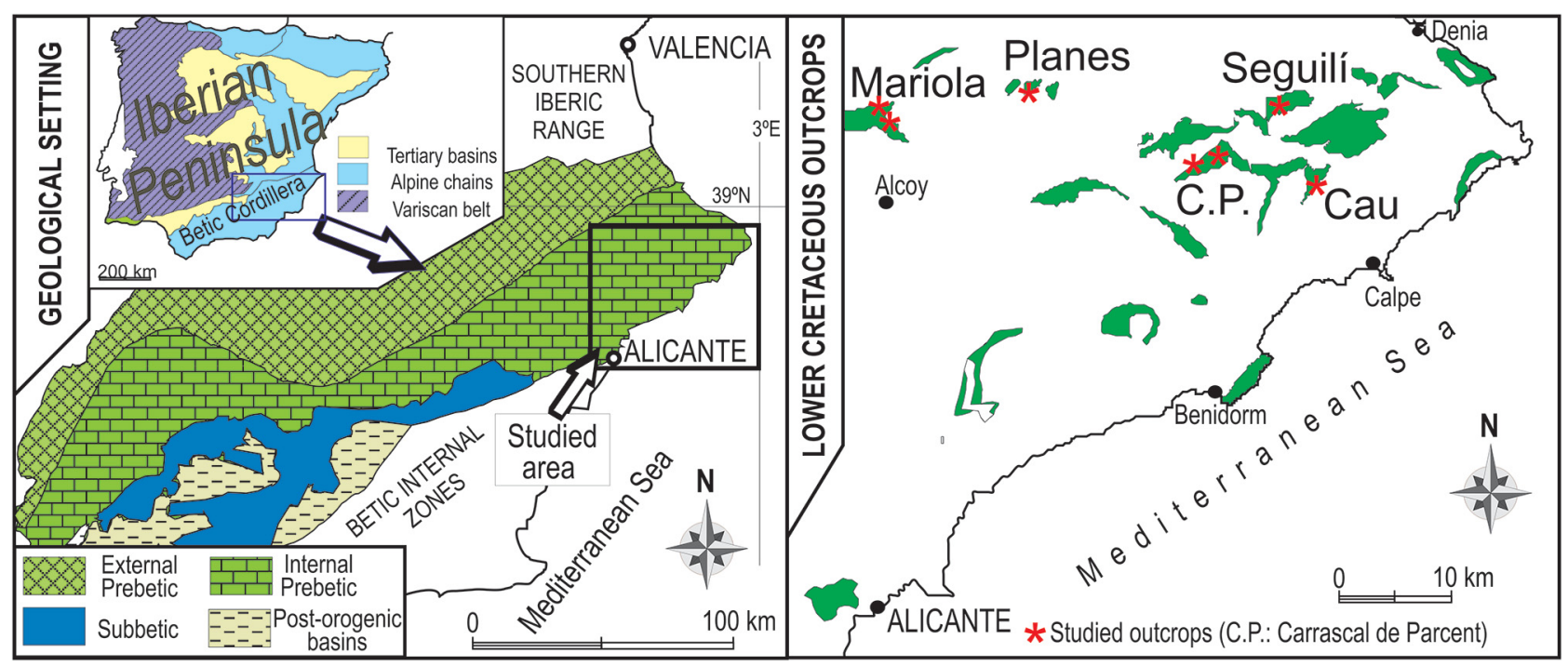

Fig. 1. Geographical and geological location of the studied sections: a: geological setting of study area in Iberia; b: studied outcrops.

framework was operative, extensional tectonics prevailed in the SIP. That extensional tectonism experienced a strong phase during the latest Jurassic to the Hauterivian, followed, during the Barremian-Aptian, by an interval of lesser tectonic movements but larger subsidence rates, which favoured the development of wide and thick carbonate platforms (including the Urgonian facies) in the shallow areas of the basins (GarcíaHernández et al., 1980; Vilas et al., 2001; García-Hernández et al., 2001, 2003; Martín-Chivelet et al., 2002; Vera, 2004; Castro et al., 2008).

Basin analysis of the Prebetic platform (Vilas et al., 1993; Martín-Chivelet et al., 2002), has allowed the characterisation of the Early Cretaceous tectonosedimentary evolution of the Prebetic area, which was controlled by persistent, multiepisodic, extensional tectonics until the late Albian, when tectonic subsidence gave way to a generalized, complex, thermal subsidence. Within this interval, the Aptian represents a main tectonosedimentary episode (K4, Martín-Chivelet et al., 2002; Alonso-Chaves et al., 2004), bounded by two major discontinuities linked to extensional tectonic events that resulted in significant changes in basin palaeogeography and subsidence patterns. This Aptian tectonosedimentary episode corresponds to a second-order sedimentary cycle in the sense of Hardenbol et al. (1998), composed of a succession of thirdorder cycles that define a general transgressive-regressive evolution (Castro, 1998; Ruiz-Ortiz and Castro, 1998; Castro et al., 2008).

During the Aptian, carbonate and siliciclastic sedimentation alternated in the proximal parts of the Prebetic, whereas towards the more distal parts of the platform, well represented in outcrops in the province of Alicante, shallow-marine carbonates and hemipelagic sediments alternate, representing the transition towards basinal settings (Castro et al., 2008).

The Aptian stratigraphic record of the Prebetic of Alicante is represented by three formations, defined from the Alicante outcrops (Castro, 1998): the Llopis Formation, made up of shallow marine limestones with rudists and corals, locally with a siliciclastic member at its top (Lower Aptian of early Bedoulian age), the Almadich Formation, composed of hemipelagic marls and marlstones (Lower-Upper Aptian of late Bedoulian to early Clansayesian age) and the Seguili Formation, with shallow marine limestones (Upper Aptianlowermost Albian of late Gargasian to earliest Albian age) (Fig. 2). The boundaries between these formations are diachronous, as the Almadich Formation records a longer time interval towards more distal, southern locations.

The main sections investigated in this study (Mariola, Planes, Seguilí, Barranco de Alcaida and Casetas del Mayor) are located in the north of the province of Alicante (Fig. 1b), and their stratigraphy, biostratigraphy and sedimentology have been previously presented in several publications by two of the authors of this study (Castro and Ruiz-Ortiz, 1995; Ruiz-Ortiz and Castro, 1998; Castro, 1998; Castro et al., 2008, 2014).

\section{The Aptian carbonate platforms}

\subsection{Earliest Aptian Llopis Formation platform}

\subsubsection{Sierra de Mariola}

The most stratigraphically extended development of the Llopis Formation crops out on the imposing north-eastern flank of the Sierra de Mariola (Fig. 3) in the north-western corner of the study area, where it reaches $210 \mathrm{~m}$ in total thickness (Castro, 1998; Castro et al., 2008; MartínezRodríguez et al., 2018). A mixed siliciclastic/carbonate lower member, some $50 \mathrm{~m}$ thick (not shown in Fig. 2 and not considered further in this work), of Late Barremian age and containing scattered rudist debris (Fig. 4a), is locally exposed on the eastern lower slopes of the sierra. This unit is succeeded by the coral- and rudist-rich basal units of the main, carbonatedominated (Urgonian facies) middle member, of earliest Aptian age (Fig. 2). The cliffs below and to the SSW of the old ruins of Llopis Farm provide spectacular exposures of largescale progradational bedding geometry in the upper part of the Llopis Formation middle member, consisting of SW-dipping, massive clinoform beds of bioclastic debris overlain by flatlying platform-top beds (Fig. 3). 


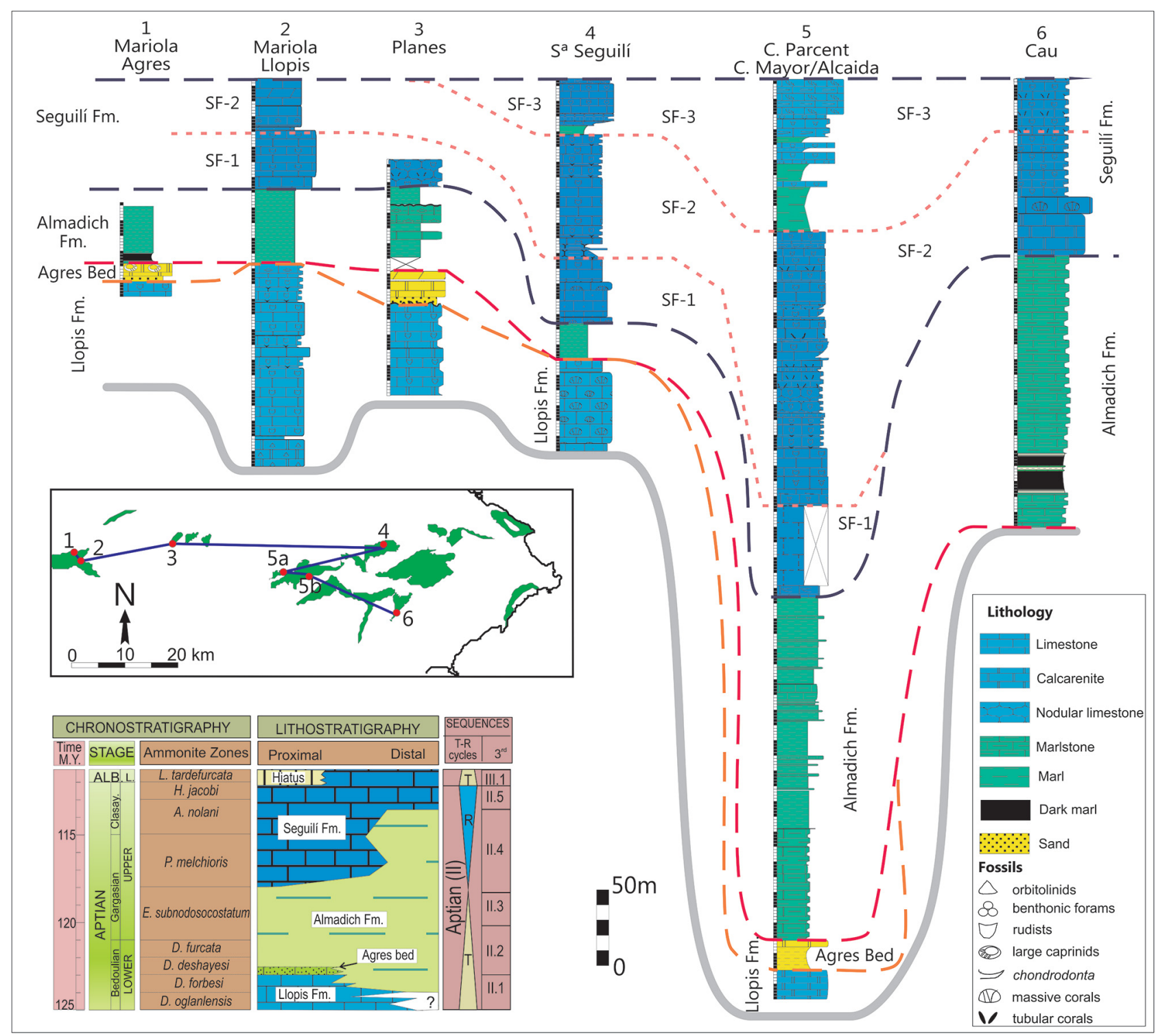

Fig. 2. Synoptic stratigraphical chart of the Aptian of the Alicante region, with location of investigated sections and chronostratigraphy. The Cau section (de Gea et al., 2003; Naafs et al., 2016) is included as a reference for the expression of OAE 1a.

The predominant facies in the upper clinoform beds are pale buff-grey coloured, fine- to coarse-grained bioclastic/ peloidal wackestones to grainstones (Fig. 4b), with coarser, miliolid-rich burrow fills visible in places. Limited patches of floatstone contain whole and fragmented macrofossils, especially chondrodontid and rudist bivalves (Fig. 4c), together with benthic foraminifers and fragments of phaceloid corals, dasycladacean algae, crinoids and bryozoans, as well as intraclasts and some quartz. Some Chondrodonta are preserved in upright life position, attached to other shell debris, but otherwise, most of the benthic biota had evidently been more or less transported prior to deposition. A more distal equivalent of the Llopis Formation slope facies is exposed in a road section just over $30 \mathrm{~km}$ to the ESE, at Casetas del Mayor in the Carrascal de Parcent Sierra (Fig. 2): there, coarse grainstones contain well-rounded rudist and other shell debris (Fig. 4d).
The platform-top beds exposed in the cliff sections at Sierra de Mariola (Fig. 3) are mostly each over 2 m thick and contain pale grey bioclastic packstones and grainstones. Cyclic stacking of biofacies within these beds is common, with rudistdominated floatstone (Fig. 5a) in their lower parts - though also including local clusters of slender elevator rudists preserved in upright life position (Fig. 5b) - passing upwards to finer-grained, more sparsely fossiliferous bed tops, which may show burrow mottling (Fig. 5c). The biota of these beds is similar to that in the upper clinoform beds, the main difference being the relatively greater abundance of rudists, including autochthonous examples, in the platform-top beds. However, pervasive leaching of the originally aragonitic inner shell of the rudists towards the top of the Llopis Formation makes identification problematical in many cases.

Some thinner cyclic beds exposed on the narrow plateau to the NNE of Llopis Farm expose more internal, predominantly 


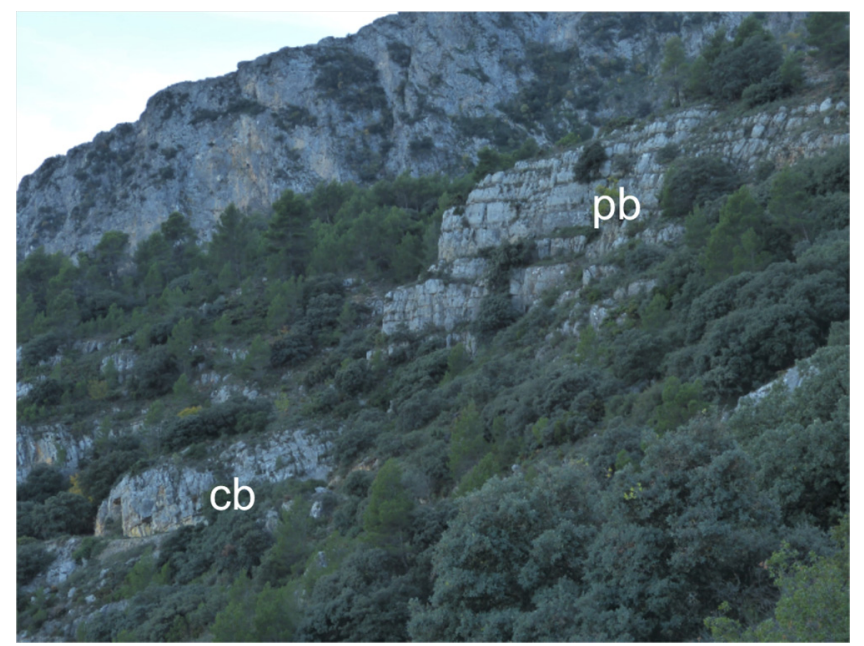

Fig. 3. Sierra de Mariola (see Fig. 1 for location): view towards SE along eastern face of the sierra, SSW of Llopis Farm (out of view to right), showing the middle member of the Llopis Formation in the foreground. Note depositional contrast in dip between clinoform beds (cb), below, and platform-top beds ( $\mathrm{pb}$ ), above.
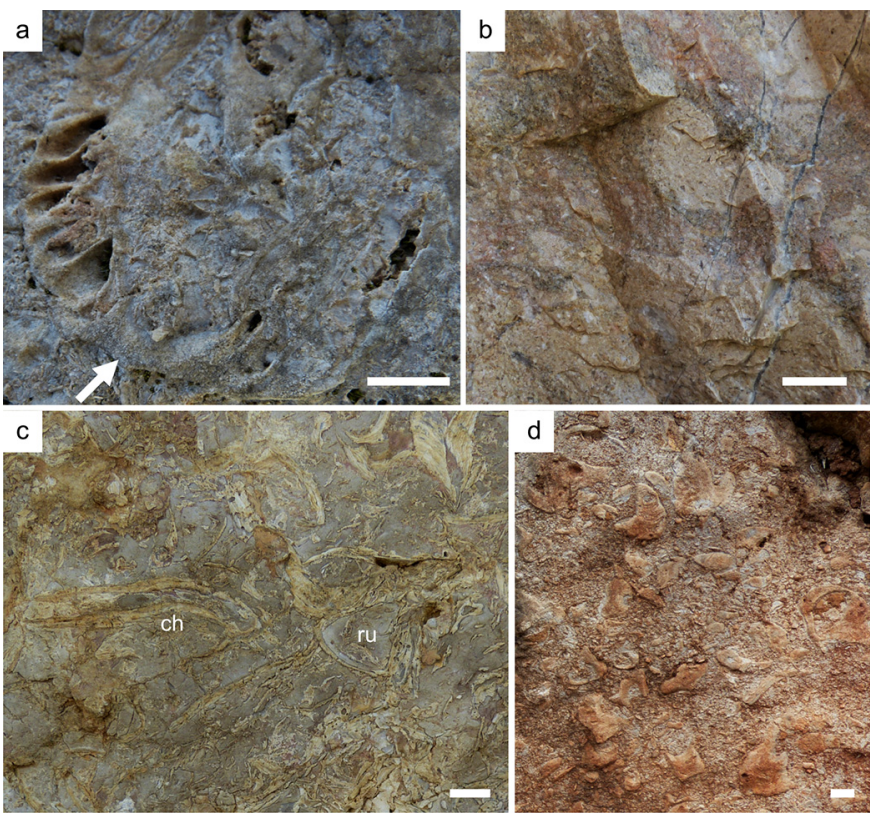

Fig. 4. Llopis Formation slope facies. (a-c) Sierra de Mariola: a: float from lower member, containing fragment of caprinid rudist, Offneria interrupta Paquier, 1905 (left valve; note diagnostic absence of canals in mid-ventral margin, arrowed, $c f$. Paquier, 1905, Pl. XI, Figs. 1517); b: middle member, bioclastic grainstone in massive clinoform bed; c: middle member, floatstone with Chondrodonta (ch) and rudists (ru); d: Casetas del Mayor, distal slope facies in lower limestones of Llopis Formation., containing rounded rudist rubble in grainstone matrix. All scale bars $=10 \mathrm{~mm}$.

micritic platform-top biofacies characterized by drifts of modestly sized molluscs, including nerinellid, itieriid and other gastropods (Fig. 5d), small, thin-shelled rudists (Figs. 5e
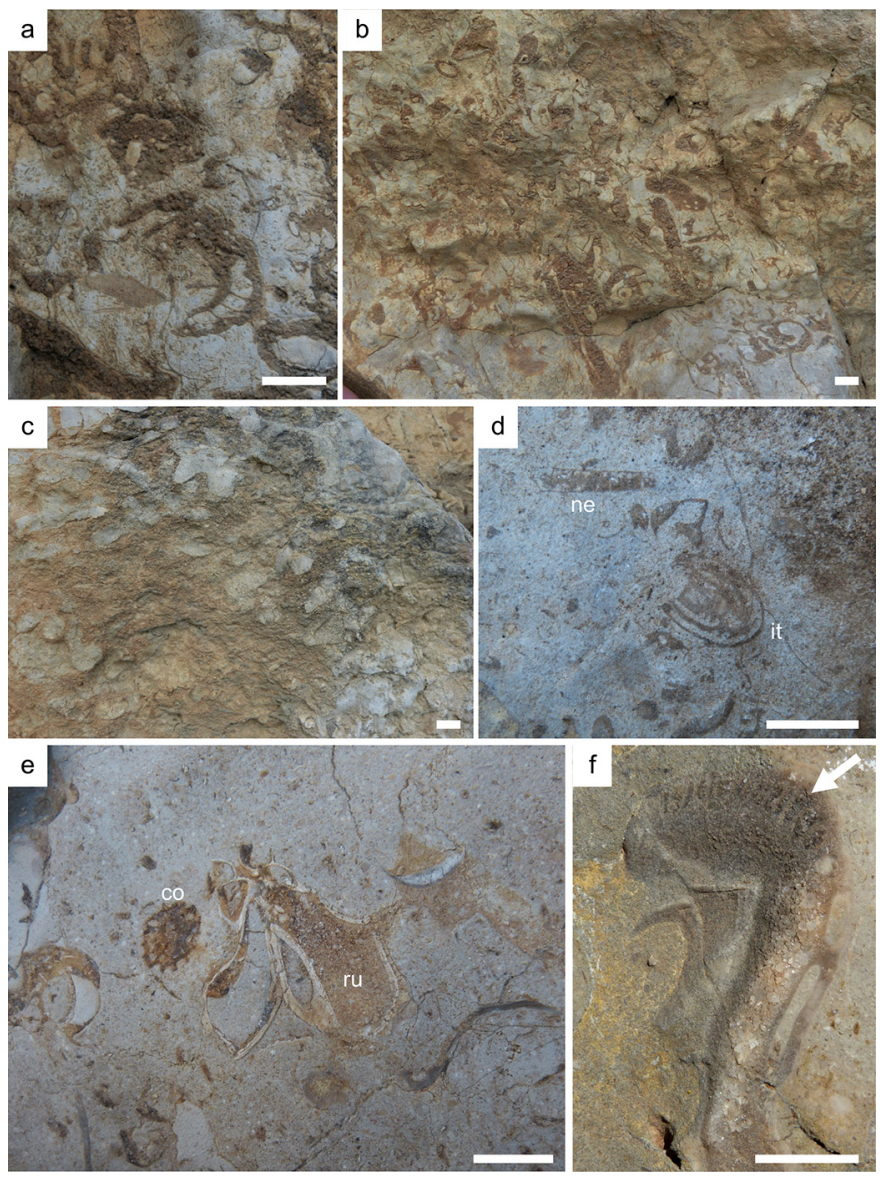

Fig. 5. Field views of platform-top facies at Llopis Farm locality, Sierra de Mariola: $(a, b)$ vertical sections showing: a: rudist floatstone; and $b$ : loose cluster of indeterminate elevator rudists preserved in upright life position; c: burrowed top of bed; (d-f) bed-top views of more internal platform-top beds, showing: d: nerineoid (probably nerinellid) (ne) and itieriid (it) gastropods (see Kollmann, 2014); e: small coral (co) and rudist (ru) debris; and f: fragment of small caprinid rudist, showing single row of simple marginal canals (arrowed), probably Caprina douvillei Paquier, 1905, left valve (see text for discussion). All scale bars $=10 \mathrm{~mm}$.

and 5f) and Chondrodonta, as well as solitary and small colonial corals, miliolid and orbitolinid foraminifers and dasycladacean algae.

\subsubsection{Sierra de Seguilí}

Some $40 \mathrm{~km}$ to the east, on the northern margin of the Sierra de Seguilí (Fig. 1b), a section through nearly $12 \mathrm{~m}$ of platform-top beds in the upper part of the Llopis Formation middle member is exposed alongside a small road south of the town of Benidoleig (Figs. 6a and 7a; Castro, 1998, section SEG 1b). Relatively easier access to, and better preservation of the strata here (Figs. 6b and 6c), compared to the Mariola exposures, allow more detailed analysis of their biofacies. This short succession shows an overall upward trend from floatstones of rudist, coral and other bioclastic debris, in a packstone to grainstone matrix (Figs. $7 \mathrm{a}-7 \mathrm{c}$ ), to rudistdominated floatstones, including some specimens preserved in 

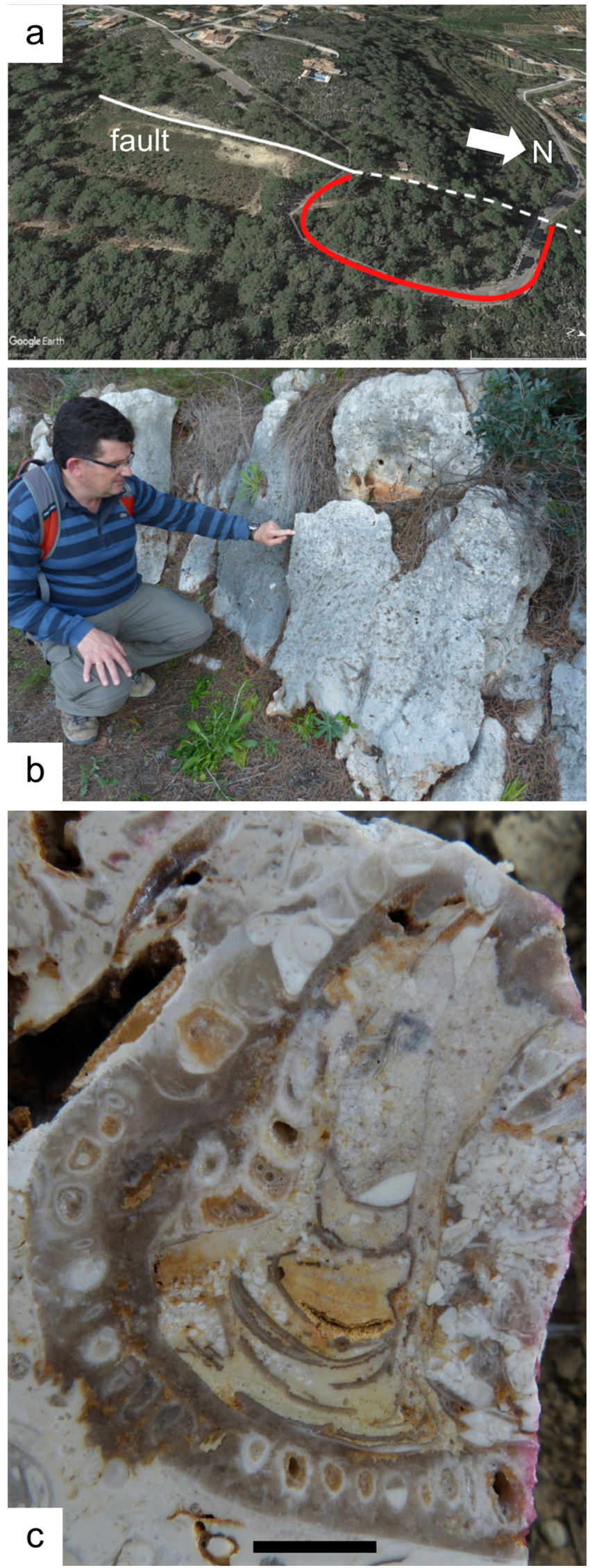

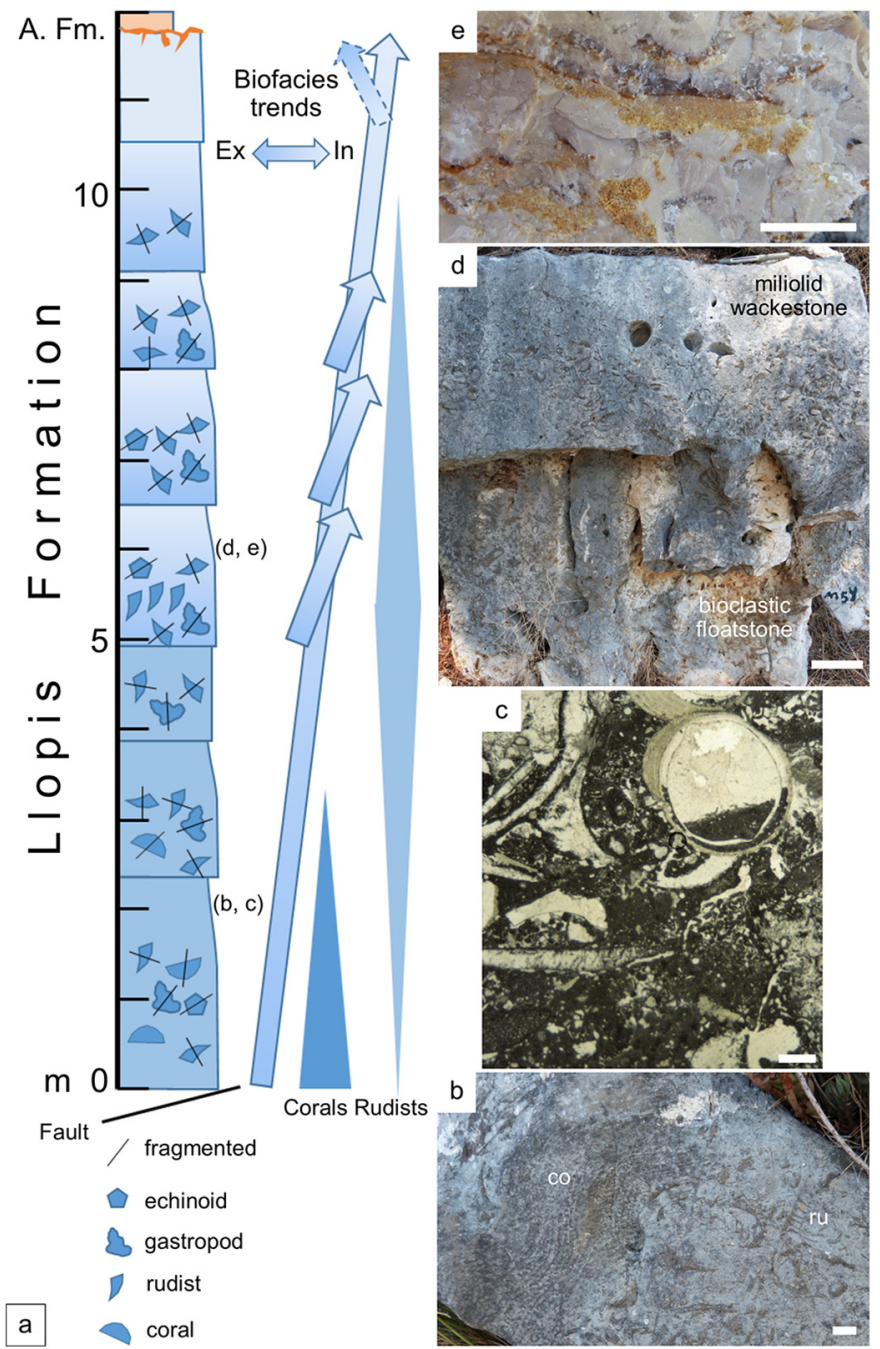

Fig. 7. Llopis Formation platform-top beds studied at Sierra de Seguilí: a: summary log of studied section showing overall, and bedscale biofacies trends (External-Internal) up to boundary with overlying Almadich Formation (A. Fm.); b: exposure of rudist (ru) and coral (co) floatstone at $0-2.4 \mathrm{~m}$ in (a); c: thin section photomicrograph from lowest bed, showing Bacinella nodule containing orbitolinid and other bioclastic debris, and perforated by lined, geopetally filled bivalve borings; (d, e) upper half of bed at 5-6.5 $\mathrm{m}$ in (a), showing inferred regressive biofacies stacking (d), and (e) fractured vertical section through microkarstic cavities at top of bed, geopetally filled with orange-coloured crystal silt. Scale bars: b, e: $10 \mathrm{~mm}$; c: $1 \mathrm{~mm}$; and $\mathrm{d}: 100 \mathrm{~mm}$.
Fig. 6. Llopis Formation at Sierra de Seguilí (see Fig. 1 for location): a: situation of road section (bold red line) exposing platform-top beds; b: example of roadside exposure (=bed shown at 5-6.5 m in Fig. 7a); c: cut surface of block recovered from repeat section of upper beds to west of fault in (a), showing adumbonal view of postero-dorsal part of left valve of large Offneria sp., most likely O. rhodanica Paquier, 1905 ( $c f$. , Paquier, 1905 P1 XII, Fig. 5), scale bar=10 mm. 


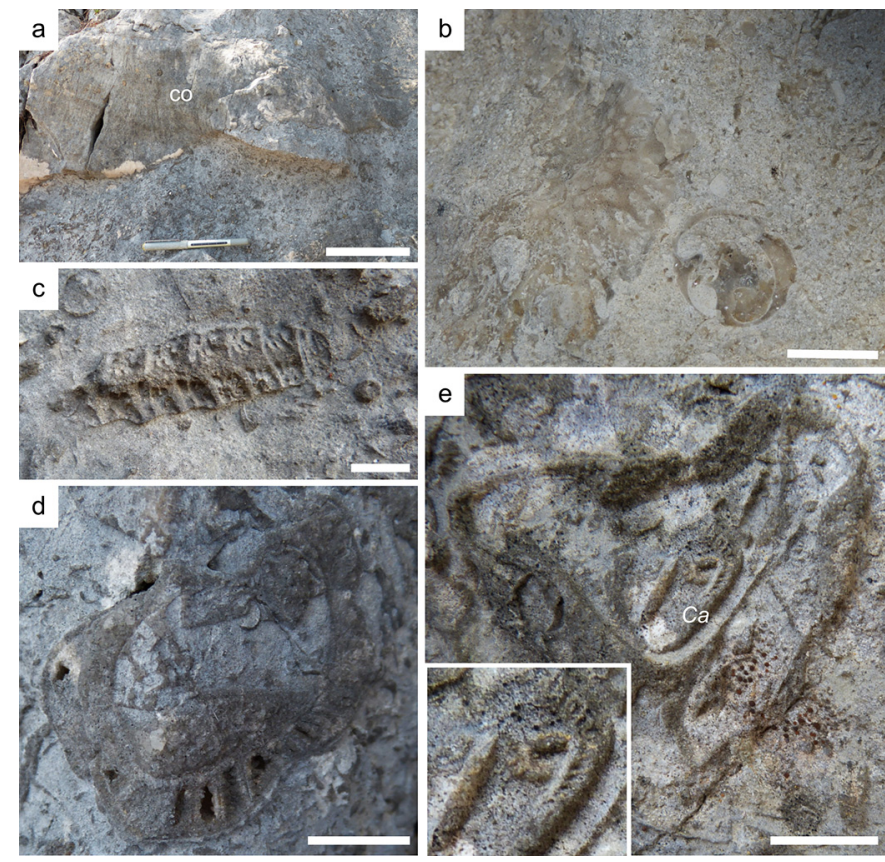

Fig. 8. Macrobiota in lower part of Llopis Formation section shown in Figure 7a: a: large colonial coral (co) of low domal form preserved in life position; b: coral and indeterminate gastropod fragments; $c$ : nerineid gastropod; (d, e): caprinid rudists, d: Offneria sp., and e: left valve of probable Caprina douvillei ( $\mathrm{Ca}$, detail shown inset; see text for discussion) within main cavity of larger, indeterminate rudist valve. Scale bars: a: $100 \mathrm{~mm}$; b-e: $10 \mathrm{~mm}$.

life position, in its upper part (Figs. 7a and 7d). We interpret this overall biofacies trend as broadly progradational, with the more disturbed, rudist/coral facies in the lower beds representing the more energetic external platform and the succeeding rudist-dominated beds having been more internally situated - in keeping both with the large-scale bedding and facies anatomy directly visible in the Sierra de Mariola, described above, and with the typical relative distributions of Cretaceous corals and rudists observed elsewhere (Skelton et al., 1997). However, a possible short-term reversal to transgression is hinted at in the topmost part of the Llopis Formation here, which will be discussed in the next section (2.2).

Although most of the macrofossils in the lower beds are fragmented, bored and/or worn (Figs. $7 \mathrm{~b}$ and $7 \mathrm{c}$ ), a few large coral colonies of low domal form are preserved in life position (Fig. 8a). The accompanying biotic components in these lower beds include Chondrodonta, various gastropods (Figs. 8b and $8 \mathrm{c}$ ), globose cidarid echinoid spines, bryozoans, calcareous sponges, orbitolinid and other benthic foraminifers, calcareous algae and Bacinella nodules (Fig. 7c), together with a few thinly coated ooids. The rudist complement of these beds mostly disarticulated or fragmentary - is dominated by caprinids, especially the large canaliculate genus Offneria (Fig. 8d), but also including Pachytraga (see below) and a rarer, miniscule taxon with a single row of simple pallial canals of pyriform cross-section (Fig. 8e, $\mathrm{Ca}$ ), most likely attributable to Caprina douvillei Paquier, 1905. Although Masse and
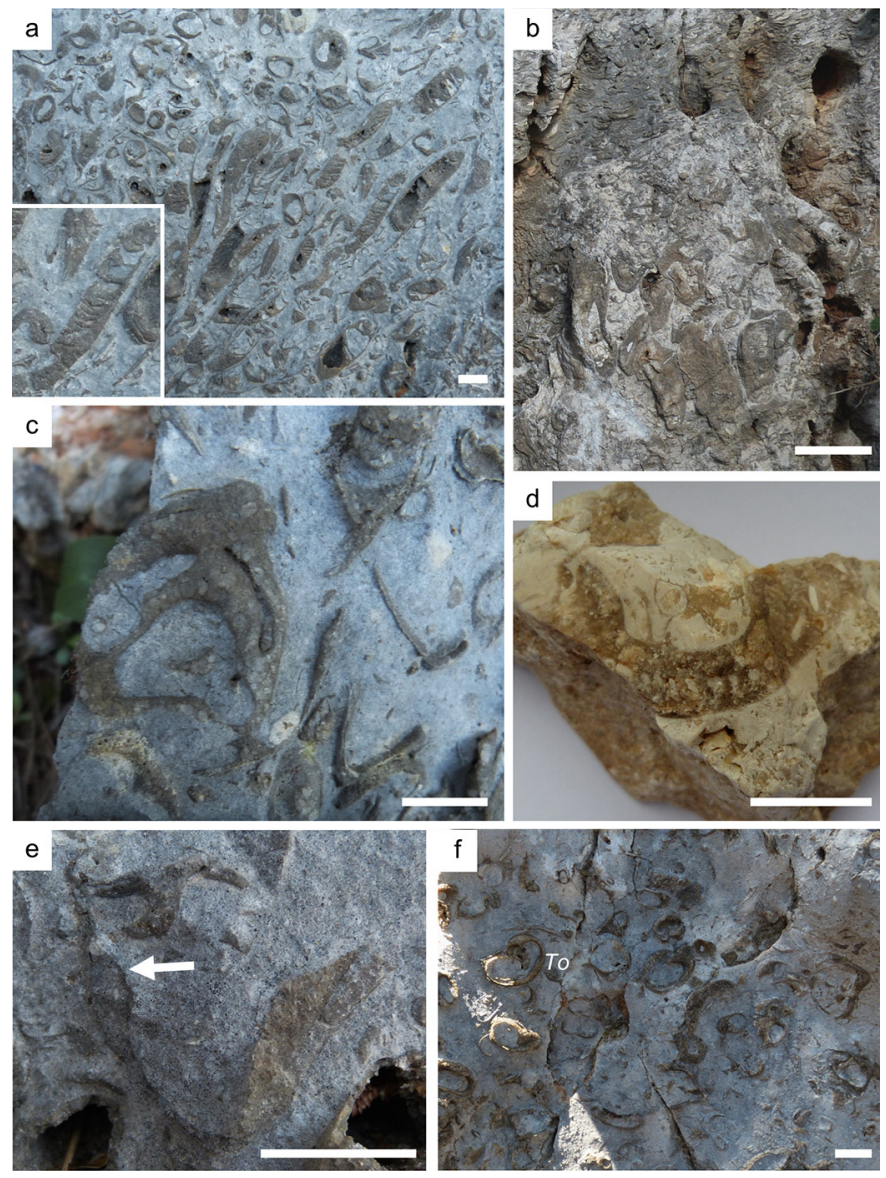

Fig. 9. Rudist floatstones in upper part of section shown in Figure 7a: a: tubular monopleurid shells dominant (probably Mathesia; inset shows detail of tabulae-see text for discussion), with cluster preserved in upright life position; b: cluster of robust caprinids (? Pachytraga, but too recrystallized for secure determination) preserved in upright life position, overlain by shell bed of horizontally oriented Chondrodonta (at top), in repeat section of upper beds to west of fault shown in Figure 6a; c: left valve of Pachytraga paradoxa (Pictet and Campiche, 1869; see Skelton and Masse, 1998); d: partial left valve of probable Caprina douvillei (see text for discussion); e: Polyconites aff., hadriani Skelton et al., 2010 (polyconitid), section through articulated shell showing characteristic posterior myophoral arrangement at left, including inwardly inclined myophore in right (lower) valve (arrowed; see text for discussion); f: small Toucasia sp. (requieniid) (To), with other rudist debris. Scale bars: a, c-f: $10 \mathrm{~mm}$; and $\mathrm{b}: 100 \mathrm{~mm}$.

Chartrousse (1997, p. 805) caution against confusing this latter species with the equally small Offneria nicolinae (Mainelli, 1983), we regard that identification as less likely in this case, as we have not, as yet, observed any examples here containing tabulae (cf., Figs. 5f and 9d). Relatively scarce fragments of other rudists include small tubular monopleurids (?Mathesia, discussed below) and Toucasia, both of which are more common in the overlying beds.

As at the Sierra de Mariola, the rudist-dominated tabular beds in the upper part of the Llopis Formation at Sierra de 


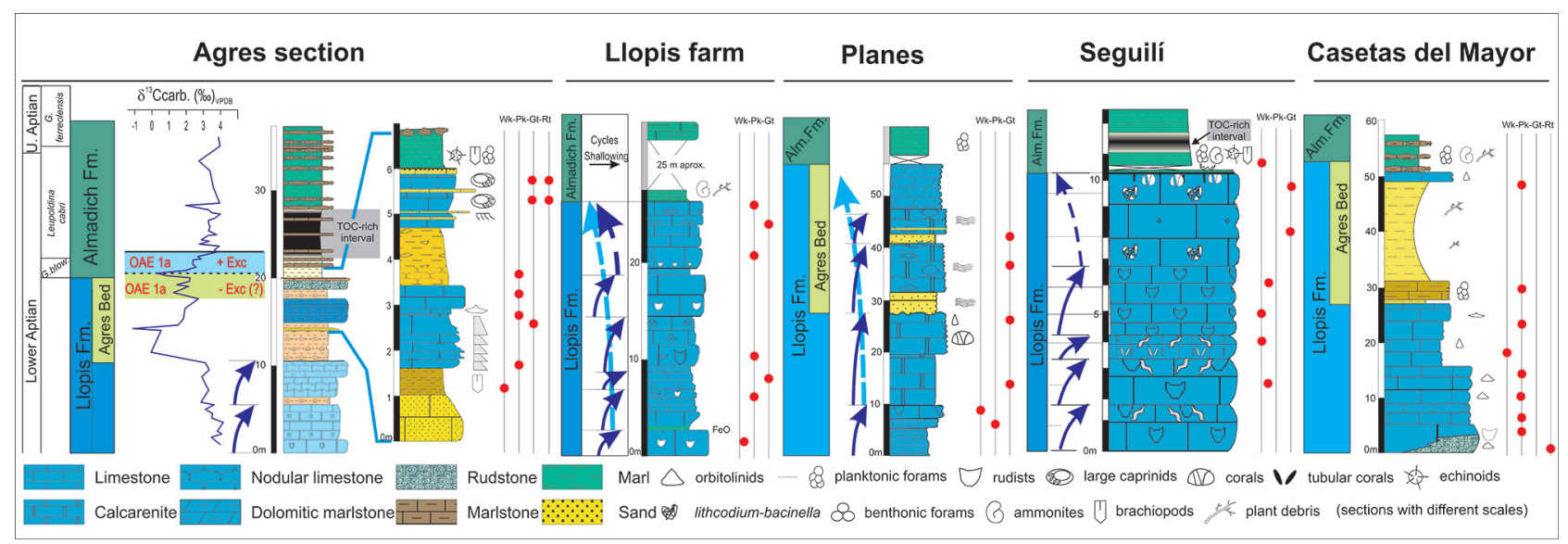

Fig. 10. Detailed logs of the termination of the Llopis Formation platform (Llopis-Almadich transition); carbon isotopic curve for the Agres section modified from Castro et al., 2014 (Fig. 2). See Figure 1 for section localities.

Seguilí show a cyclic stacking of biofacies (especially those from $5 \mathrm{~m}$ upwards on the log in Fig. 7a). Each bed consists mostly of closely packed floatstone, with a matrix of miliolidrich bioclastic packstone, capped by miliolid-rich wackestones containing sparse macrofossils (Fig. 7d). We interpret these repetitively shallowing beds as representing successive minor regressive cycles - an interpretation supported in a few cases by the presence at their tops of microkarstic cavities with geopetal fills of orange-coloured crystal silt (Fig. 7e), indicating emergence.

Locally, clusters of elevator rudists are preserved in life position in the lower parts of these cyclic beds (Figs. 9a and $9 \mathrm{~b})$. Though caprinids are again common in this part of the section, especially Pachytraga paradoxa (Figs. 9b and 9c; see Skelton and Masse, 1998), together with Offneria spp., including both $O$. rhodanica Paquier, 1905 (Fig. 6c), and $O$. interrupta Paquier, 1905 (the latter according to Chartrousse, 1998, p. 84) and Caprina douvillei (Fig. 9d), they are here copiously accompanied by other rudists. Prominent among the latter is a slender tubular monopleurid (Fig. 9a), tentatively assigned to Mathesia sp., on account of its possession of tabulae, which are known in this genus (see later), but not as yet recorded in the externally similar Debrunia (Masse and Fenerci-Masse, 2009). However, we have not yet been able to confirm the presence in this form from the Llopis Formation of the diagnostic fine longitudinal tubes around the inner margin of the outer shell layer (Masse and Fenerci-Masse, 2010), hence, its tentative status (though it is worth noting that $M$. darderi (Astre, 1933) has been identified at Sierra de la Muela, to the west of the study area, in upper Barremian beds (FenerciMasse et al., 2011). Also present is a small polyconitid (Fig. $9 \mathrm{e})$ with a posterior myophoral organization approaching that of Polyconites hadriani Skelton et al., 2010-notably showing a depressed inward inclination to the posterior myophore in the right (lower) valve, in contrast to the projecting inner rim of that seen in its putative ancestral genus, Horiopleura (Skelton et al., 2010), even including the "slightly depressed" myophore noted in the figured type specimens of $H$. brevis (Masse and Fenerci-Masse, 2017). The requieniid clinger Toucasia (Fig. 9f) is relatively more frequent in some of the upper beds. The non-rudist bivalve Chondrodonta is common throughout the section, in at least one instance forming a dense shell bed of horizontally oriented valves capping rudist floatstone (e.g., Fig. 9b).

Thus, caprinid rudists, with robust, originally almost wholly aragonitic shells, dominate the external platform-top facies, while the relatively more internal facies contain a mix of monopleurid, polyconitid and requieniid rudists, all of which show slightly thicker development of the calcitic outer shell layer relative to caprinids, together with the caprinids. This pattern of rudist distribution on the platform top is consistent with that found in previous studies of Tethyan platforms of Early Aptian age (Fenerci-Masse, 2006; Skelton and Gili, 2012).

A thin, more siliciclastic-bearing upper member of the Llopis Formation is present only locally (for example, in the Agres section on the Sierra de Mariola; Fig. 2), showing some striking contrasts with the typical "Urgonian"-type facies of the main part of the formation described above. As this regionally variable upward passage from the Llopis Formation to the basal part of the Almadich Formation offers important clues to possible reasons for the demise of the Llopis Formation platform, we describe it in detail in the following section.

\subsection{Termination of the Llopis Formation platform}

The record of the termination of the Llopis Formation platform consists of a complex transition from the rudistbearing shallow platform carbonates of the Llopis Formation to the marls and marlstones with ammonites of the Almadich Formation, with interesting lateral variations revealed by the different sections studied (Fig. 10).

\subsubsection{Seguilí section}

The topmost part of the Llopis Formation in this section presents an abrupt facies change, marked also by the disappearance of rudists (Fig. 10). The facies of the uppermost $2 \mathrm{~m}$ of the Llopis Formation here consists of fine-grained, 

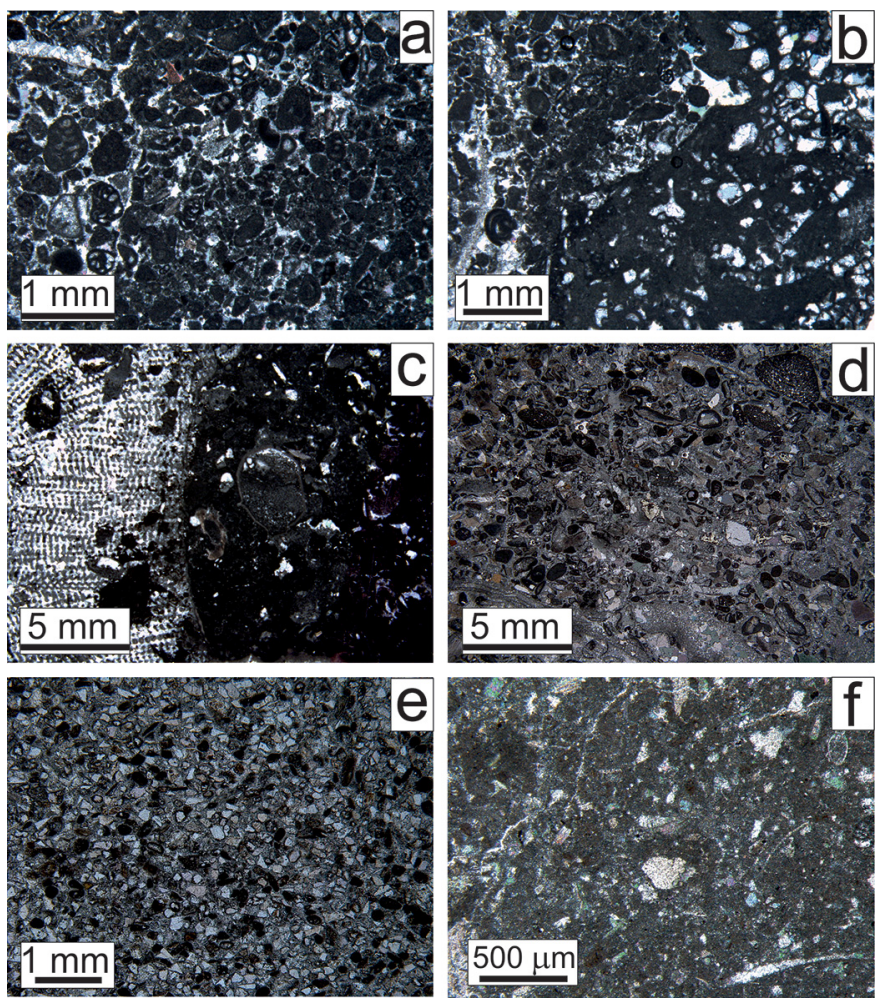

Fig. 11. Microfacies from top of Llopis Formation. (a-c) Seguilí section: a: fine grainstone with peloids, intraclasts and small benthic foraminifers; b: Lithocodium-Bacinella nodule embedded in fine grainstone; c: bored coral with micritic sediment and geopetal fillings. (d, e) "Agres bed", Agres section (see Fig. 10): d: poorly sorted bioclastic sandy grainstone; e: fine grained, well sorted, calcareous sandstone; f: silty bioclastic marl microfacies of Llopis/Almadich transition at Casetas del Mayor.

moderately sorted grainstones with peloids, intraclasts and small foraminifers (Fig. 11a), and some LithocodiumBacinella nodules (Fig. 11b). The uppermost bed has bored corals, embedded in micritic sediment with geopetal structures (Fig. 11c). The top surface of the section shows partially dissolved borings in the coral-rich level (Fig. 12a), is slightly irregular and is covered by a marly crust with ammonites and planktonic foraminifers. The marly basal part of the Almadich Formation is poorly exposed and, moreover, is locally obscured by a fault (Fig. 6a). Where the Llopis/Almadich boundary succession is preserved, a thin observational gap of a few $\mathrm{cm}$ is followed by a section of about $10 \mathrm{~m}$ of beige marls and marlstones with rare ammonites and containing a $65-\mathrm{cm}$ thick level of darker grey shaley marl at its base (Figs. 10 and 12b). This facies succession is interpreted as the result of a change to more open marine conditions during the last part of the deposition of the Llopis Formation, with development of fine grainstones finally colonized by corals. The top surface indicates an interruption in sedimentation, with a probable episode of emersion, leading to the development of microkarst with geopetal sedimentary filling. After the interruption, sedimentation resumed in deeper open marine hemipelagic conditions, characteristic of the Almadich Formation. We suggest that the dark layer at its base may correspond to the lithologically similar
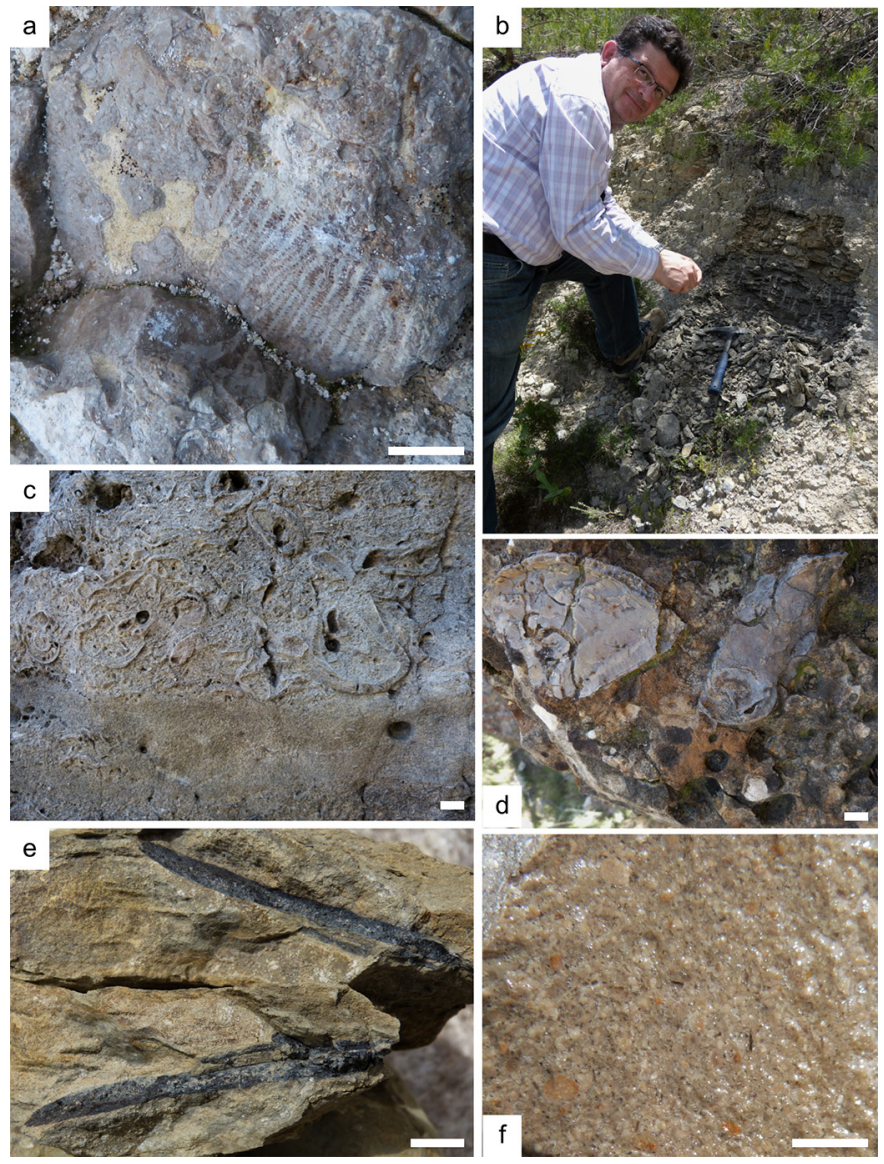

Fig. 12. (a, b) Sierra de Seguili: a: top surface of Llopis Formation, with bored and partially dissolved coral in hardground surface and; $b$ : dark marl (above hammer) in basal Almadich Formation. (c, d) Llopis Formation upper member at Agres: c: calcarenite with caprinid rudstone above and; d: and oyster-encrusted firmground at top. (e, f) Terminal Llopis Formation facies at Casetas del Mayor: e: siltstone with plant fragments and; f: finely comminuted bioclastic grainstone of topmost bed. Scale bars: a, c-e: $10 \mathrm{~mm}$; and $\mathrm{f}: 1 \mathrm{~mm}$.

interval in the lower part of the nearby, more basinward Cau section (Fig. 2), which has in turn been interpreted as an expression of OAE1a (de Gea et al., 2003; Naafs et al., 2016; Ruiz-Ortiz et al., 2016).

\subsubsection{Mariola-Llopis farm section}

In this section, the uppermost beds $(\sim 25 \mathrm{~m})$ of the Llopis Formation are limestones with rudists and orbitolinids, making part of a succession of shallowing upwards cycles that ends with a last cycle $7.5-\mathrm{m}$ thick, with planar orbitolinids, crinoids, and less frequent bryozoans, Lithocodium-Bacinella and quartz (Fig. 10). The top is marked locally by a slightly ferruginous surface, passing laterally into a more gradual transition. The base of the Almadich Formation is a marlstone with planktonic foraminifers and some planar orbitolinids, together with some small irregular echinoids and terebratulide brachiopods and encrusting bryozoans, which grades upwards into marls and marlstones with ammonites. The sedimentary 
Table 1. List of benthonic foraminifers and rudist bivalves from the Llopis Formation.

\begin{tabular}{ll}
\hline Benthic foraminifers & Rudist bivalves \\
\hline $\begin{array}{l}\text { Choffatella decipiens } \\
\text { Schlumberger }\end{array}$ & $\begin{array}{l}\text { Offneria interrupta } \\
\text { Peotrocholina } \text { sp. }\end{array}$ \\
& $\begin{array}{l}\text { Offneria rhodanica } \\
\text { Paquier (Fig. 6c) }\end{array}$ \\
Palorbitolina lenticularis & Caprina douvillei Paquier \\
Blumenbach & (Figs. 5f, 8e, 9d) \\
Orbitolinopsis [O.] & Pachytraga paradoxa \\
cuvillieri Moullade & (Pictet and Campiche) \\
O. kiliani Silvestri & (Fig. 9c) \\
& Polyconites aff. \\
O. buccifer Arnaud- & ?Madriani (Fig. 9e) \\
Vanneau \& Thieuloy & Toucasia sp. (Fig. 9f) \\
O. praesimplex Schroeder & \\
O. pygmaea Arnaud-Vanneau & \\
Paracoskinolina maynci Chevalier & \\
\hline
\end{tabular}

evolution recorded in this outcrop is somewhat similar to that of the Seguilí section, with a reversal of the shallowing upward evolution of the Llopis platform in its uppermost part. The transition to the hemipelagic conditions marked by the Almadich do not show evidence for erosion, and the interruption is less marked, probably related to a gradual deepening across the Llopis-Almadich transition.

\subsubsection{Mariola-Agres section}

This section is located some $3.5 \mathrm{kms}$ to the north of Llopis Farm, over an almost continuous outcrop in the same large anticline, so they are interpreted as having been separated palaeogeographically by approximately that distance. Notwithstanding the short distance between the sections, they present marked differences. In the Agres section, the Llopis Formation contains a new stratigraphic unit below the Almadich Formation, the 'Agres bed', defined as the upper member of the Llopis Formation (Castro, 1998) (Fig. 10). The uppermost part of the Llopis Formation middle member (some $10 \mathrm{~m}$ in outcrop), below the Agres bed, consists of well-bedded rudist limestones with bioturbated tops and wackestonepackstone textures. The Agres bed is composed of $10 \mathrm{~m}$ of calcarenites, calcirrudites with caprinids (mainly fragments of large Offneria; Fig. 12c), marls and sands (Figs. 11d and 11e), with some current structures, including hummocky crossstratification. The top surface of this unit is a bored surface with encrusted ostreids (Fig. 12d), interpreted as a firmground formed during an interruption of sedimentation. The base of the Almadich Formation here is a $2-\mathrm{m}$ thick level of brown marls with marlstones, followed by $4.5 \mathrm{~m}$ of dark marls enriched in TOC (maximum $0.55 \%$, Castro et al., 2014). The succession continues with an alternation of marls and marlstones with planktonic foraminifers and some ammonites, with a total thickness of $65 \mathrm{~m}$ up to the end of the outcrop. The C-isotope data show a negative peak at the base of the Almadich Formation of $0.3 \%$, followed by a positive excursion from 0.3 to $3.9 \%$ with highest values within the
TOC-rich interval, together defining a Carbon isotope excursion (CIE), followed by a $\sim 15 \mathrm{~m}$ interval with similar values (Fig. 10), then by a marked decrease up to the top of the Lower Cretaceous (Castro et al., 2014). The lower part of the Almadich Formation in this section has been interpreted as the local expression of OAE1a (Castro et al., 2014).

In this section, the most striking feature is the presence of the Agres bed, reflecting an important siliciclastic input at the termination of the platform, under high energy conditions, probably with deposition of storm beds. The facies changes recorded within the Agres bed indicate a complex evolution with different pulses of low energy (marls) and high energy (sandstones, sands, calcarenites, rudist rudstones), collectively indicating an open marine environment with mixed carbonate and terrigenous sediment sources. The top of this unit is a surface of sedimentary interruption, with borings and encrusting bivalves, marking a sharp change towards the overlying hemipelagic sediments of the Almadich Formation.

\subsubsection{Planes section}

This section is located $12 \mathrm{~km}$ to the east of Mariola and, although the carbonates of the Llopis Formation are irregularly dolomitized and the section is partly covered, it permits the observation of the upper part of the Llopis and the middle part of the Almadich Formations. The uppermost part of the Llopis Formation here records a transition from rudist floatstones to bioclastic grainstones with coral debris, which are capped by an erosional surface. On top of this surface, there is a $24-\mathrm{m}$ thick unit of alternating sands and calcarenites (bioclastic grainstones with orbitolinids), both with hummocky crossstratification (Fig. 10). This unit is interpreted as the local record of the Agres bed. Above a 10-m thick covered interval, the marls of the Almadich Formation crop out, and are dated as late Bedoulian (L. cabri biozone) from the content of planktonic foraminifers (Castro, 1998).

\subsubsection{Casetas del Mayor section}

This section is located in the Sierra del Carrascal de Parcent, $30 \mathrm{~km}$ to the East of the Sierra de Mariola (Fig. 2) and represents the most distal environments of those included in this study. In these outcrops (Fig. 10), the distal slope rudist rudstone in the lower part of the Llopis Formation mentioned in the previous section $(2.1 .1$, Fig. 4 d) is succeeded by a $30-\mathrm{m}$ thick succession of packstones with some orbitolinids and bioclasts of bivalves, crinoids, and benthic foraminifers, with small amounts of quartz. The upper part of the Llopis Formation here is represented by an $18-\mathrm{m}$ thick unit of silty marls with quartz, wood fragments (Fig. 12e) and some ferruginous concretions, followed by a $2-\mathrm{m}$ thick level of finegrained bioclastic grainstones (Fig. 12f) to packstones with orbitolinids, benthonic bioclasts, and scarce planktonic foraminifers. The transition to the Almadich Formation is a net facies change towards a rhythmic succession of pale brown micritic silty marlstones and marly limestones (Fig. 11f) with ammonites and planktonic foraminifers. In this area, the most distal of those studied here, there is no evidence of sedimentary interruption at the top of the Llopis platform but, similarly to other sections, there is evidence of a notable siliciclastic input predating the installation of the hemipelagic environments of the Almadich Formation. 
2.2.6 The timing of the termination of the Llopis Formation and its correlation with the signature of OAE1a

The age of the Llopis-Almadich transition has been determined by reference to orbitolinid and rudist data from the Llopis Formation (Tab. 1), constrained by ammonites in its lowest part, and from the ammonites, planktonic foraminifers and calcareous nannofossils of the Almadich Formation. In combination, these data indicate an early Aptian (Bedoulian) age for the top of the Llopis Formation (Castro, 1998; Castro et al., 2001).

While the youngest ammonites found in the lowermost beds of the Llopis Formation in the Sierra de Mariola can be assigned a Late Barremian, Feriaudianus Zone age (Castro 1998, p. 55: Hemihoplites cf., feraudianus d'Orbigny, H. cf., soulieri Matheron and $H$. astarte Fallot and Termier), the association at the base of the slightly more distal section of this formation in the Sierra de la Solana, immediately south-east of the Sierra de Seguilí, encompasses a terminal Barremian to earliest Aptian range in age (Castro 1998, p. 140: Kutatissites sp., Ancyloceras sp., Procheloniceras cf., pachistefanum Uhlig, Pseudohoploceras sp., and Barremites strettostoma Uhlig). So, although the orbitolinid and rudist taxa cited in Table 1 might otherwise be considered to allow a relatively broad Late Barremian to Early Aptian possible age bracket (e. g., Clavel et al., 2013) for the middle to upper members of the Llopis Formation, the ammonite data cited above further constrain it to the Early Aptian.

The lower part of the Almadich Formation in the Sierra de Mariola has also been dated from ammonites (Busnardo et al., 1968; Company et al., 1982; Castro, 1998), which indicate an age corresponding to the Deshayesites deshayesi biozone (Charollais et al., 1994; Reboulet et al., 2011, 2014), i.e., the early part of the late Bedoulian. Data from the Casetas del Mayor section indicates a slightly older age for the base of the Almadich Formation in that section (from the presence of Deshayesites cf. euglyphus), corresponding to the Deshayesites forbesi biozone, and probably to its upper part, the subzone of Roloboceras hambrovi (according to MorenoBedmar et al., 2009, 2012). More recent data on planktonic foraminifers (Castro et al., 2014) show that the base of the Almadich Formation in the Mariola-Agres section belongs to the Globigerinelloides blowi biozone, consistently with the age obtained for the base of the Almadich in the Seguili section (Castro, 1998). In addition, the boundary with the overlying Leupoldina cabri biozone is some $2.3 \mathrm{~m}$ above the base of the Almadich in the Agres section, where it marks also the base of the OM-enriched levels of the OAE 1a, and the base of the positive C-isotope excursion of this event (Fig. 10; Castro et al., 2014).

Collectively, these data support a correlation between the termination of the Llopis platform and the onset of OAE1a (as now conventionally defined: e.g., Jenkyns, 2018). The Cau section, located $10 \mathrm{~km}$ to the south of the Seguili section, and deposited in a more distal location within the Prebetic platform, records the complete Lower Aptian in the hemipelagic facies of the Almadich Formation (Castro, 1998; Aguado et al., 1999), and has provided a distinctive C-isotope stratigraphy, with recognition of the isotope segments defined by Menegatti et al. (1998), (de Gea et al., 2003;
Moreno-Bedmar et al., 2012; Naafs et al., 2016; Ruiz-Ortiz et al., 2016). This section reveals a coincidence between the base of the L. cabri biozone and the boundary between $\mathrm{C}$ isotope segments $\mathrm{C} 3-\mathrm{C} 4$, which is in agreement with data from La Bédoule, in SE France (Lorenzen et al., 2013). Hence, the termination of the Llopis platform occurred clearly before the beginning of the positive $\mathrm{C}$-isotope excursion (C4 segment of Menegatti et al., 1998) of OAE1a (Fig. 10) - consistently with the appearance of the dark shaley marls in the basal Almadich Formation a little above the top of the Llopis Formation in both the Mariola-Agres and Seguili sections (Figs. 10 and 12b). This termination would thus probably have occurred during the $\mathrm{C} 3$ isotope segment, which has been estimated to have lasted about $300 \mathrm{ky}$ (e.g. Huck et al., 2011; Hu et al., 2012), although other authors have proposed a shorter interval, of $22 \mathrm{ky}$ to $44 \mathrm{ky}$ ( $\mathrm{Li}$ et al., 2008; Malinverno et al., 2010). Therefore, further investigations are needed to increase the precision of our correlation, to establish the time interval that elapsed between the termination of the Llopis Formation and the initiation of the $\mathrm{C}$-isotope positive excursion. It is worth noting that this time interval is coeval with a pulse in the extensional tectonics that affected the SIP (Martín-Chivelet et al., 2002). Block-tilting could thus have given way to new depocentres where terrigenous sediments preferentially accumulated, while at the same time, the higher parts became emergent. All this would have resulted in the lateral differences detected in the record of the Llopis-Almadich transition. This event has been widely recorded in the Tethyan and proto-Atlantic domains (e.g. Millán et al., 2009; Najarro et al., 2011; Masse and Fenerci-Masse, 2011, 2013a, 2013b; Moreno-Bedmar et al., 2012, 2014; Frau et al., 2017; among others), but the precise dating and correlation is still a matter of discussion and ongoing research (e.g. Frau et al., 2017).

\section{Late Aptian to Early Albian Seguilí platform}

The Almadich Formation passes upward to a second major carbonate platform development in the Alicante region. The first step of progradation took place in the mid-Gargasian, corresponding to the top of the E. subnodosocostatum ammonite biozone (Fig. 2; Castro et al., 2008). Three main phases of carbonate platform development are recorded from the mid-Gargasian up to the earliest Albian (Figs. 2 and 13; SF1 to SF-3). They comprise two over-stepping progradational sequences (in the mid-Gargasian and mid-Clansayesian), succeeded by a retrograded progradational sequence, all three recorded in the Seguilí and Carrascal de Parcent areas as a multi-phase carbonate platform (Fig. 13). The last sequence is coeval with a stratigraphic discontinuity in the Sierra de Mariola section (Fig. 2), probably extending towards the more proximal sectors of the Prebetic platform (Castro, 1996; Castro et al., 2008).

The first step of progradation over the hemipelagic sediments of the Almadich Formation in the Sierra de Seguili is recorded by a transition from nodular marly limestones with sparse ammonites and irregular echinoids to pale buff sandy limestones with orbitoline fragments (Fig. 13, SF-1; Fig. 14a) 


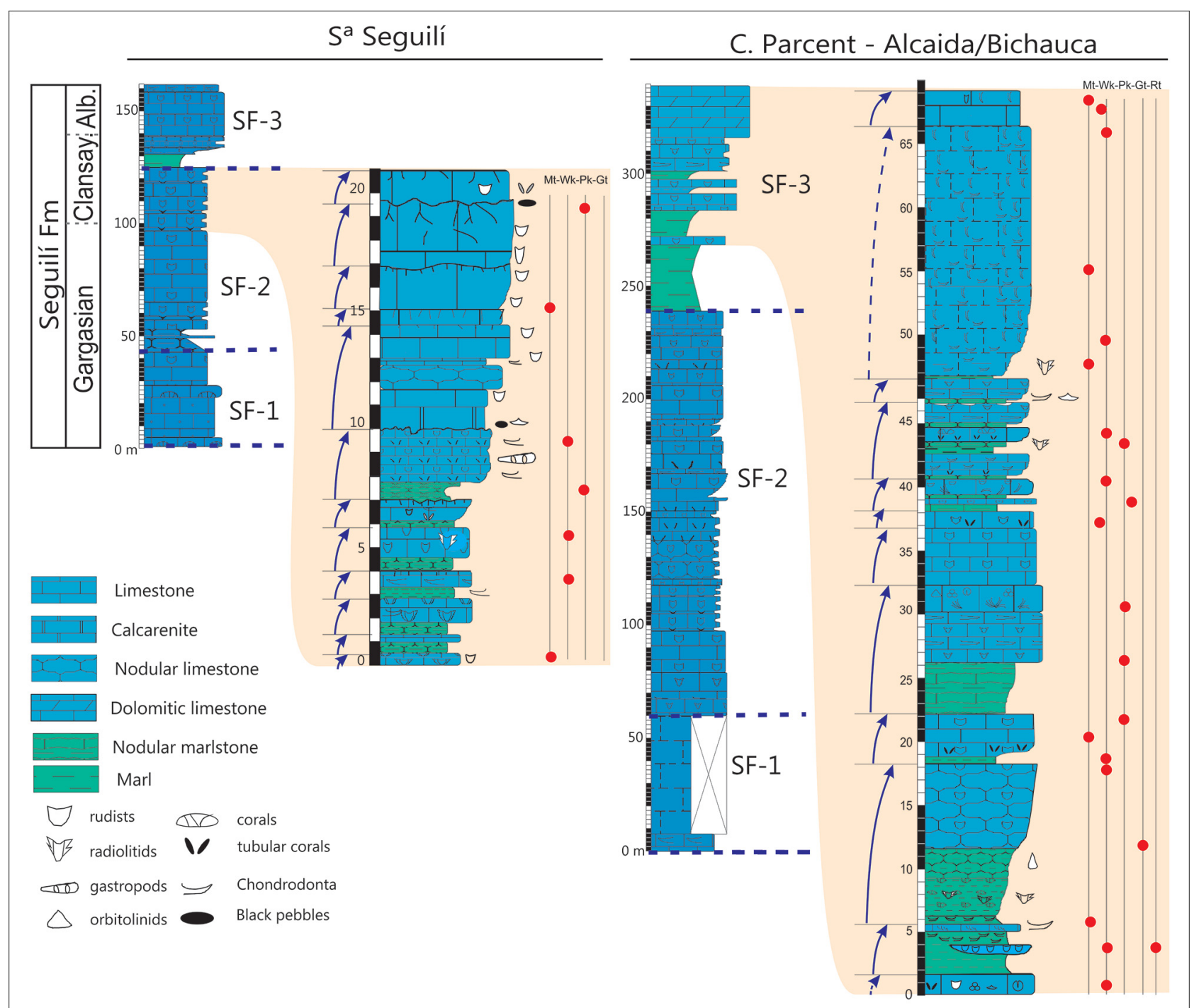

Fig. 13. Summary logs for Seguilí Formation in the Sierra de Seguilí and the Carrascal de Parcent, showing the three successive sequences of platform development, with details of the sections studied in this work. See Figure 1 for locations of sections.

in which first corals, then rudists re-appear. Likewise, coarse coral and other bioclastic debris herald the progradation of the third, youngest sequence in the Barranco de Alcaida (Fig. 13, SF-3; Fig. 14b). And as in the lower Aptian Llopis Formation platform, tabular platform-top beds again show a pattern of repeated cyclic regression, involving dense rudist and/or chondrodont floatstones (e.g., Figs. $14 \mathrm{c}$ and 14d), with localized shell clusters preserved in life position (Figs. 15ac, $16 \mathrm{a}$ and 16b,), overlain by sparser floatstones with miliolidbearing wackestone matrix, including micro-geopetal structures (Figs. 14e and 14f) and in some cases burrows containing secondary orange-stained fills suggestive of emersion (e.g., Fig. 15d).

Nevertheless, in the Seguilí Formation platform successions, the facies associations are more variegated, with the appearance of marly nodular levels in the basal parts of the cycles, infilling underlying burrows (Fig. 16e), and the development of microkarst, breccia and black pebble horizons in parts of the succession. These last-named features mark the maximum regression intervals, which heralded the initiation of the successive episodes of carbonate platform development, considered as third-order depositional sequences by Castro et al. (2008). Also, characteristic of the Seguilí Formation is the greatly increased development of Chondrodonta biofacies, relative to the Llopis Formation. This biofacies is made of dense clusters of these large bivalves, with thick, oyster-like foliaceous calcite shells (Fig. 14d), which show repeated cycles of accumulation of horizontally oriented shells followed by vertically organized shells, embedded in wackestones (Figs. 16a and 16b), with a similar growth fabric to those described by Posenato et al. (2018) from the lower Aptian of the Gargano Peninsula in SE Italy. This type of facies is best developed and shows larger specimens in the Clansayesian and lowermost Albian levels, and has also been described in sections from the upper Aptian of the Basque-Cantabrian basin (Gómez-Pérez et al., 1999; Millán et al., 2014). Nevertheless, 

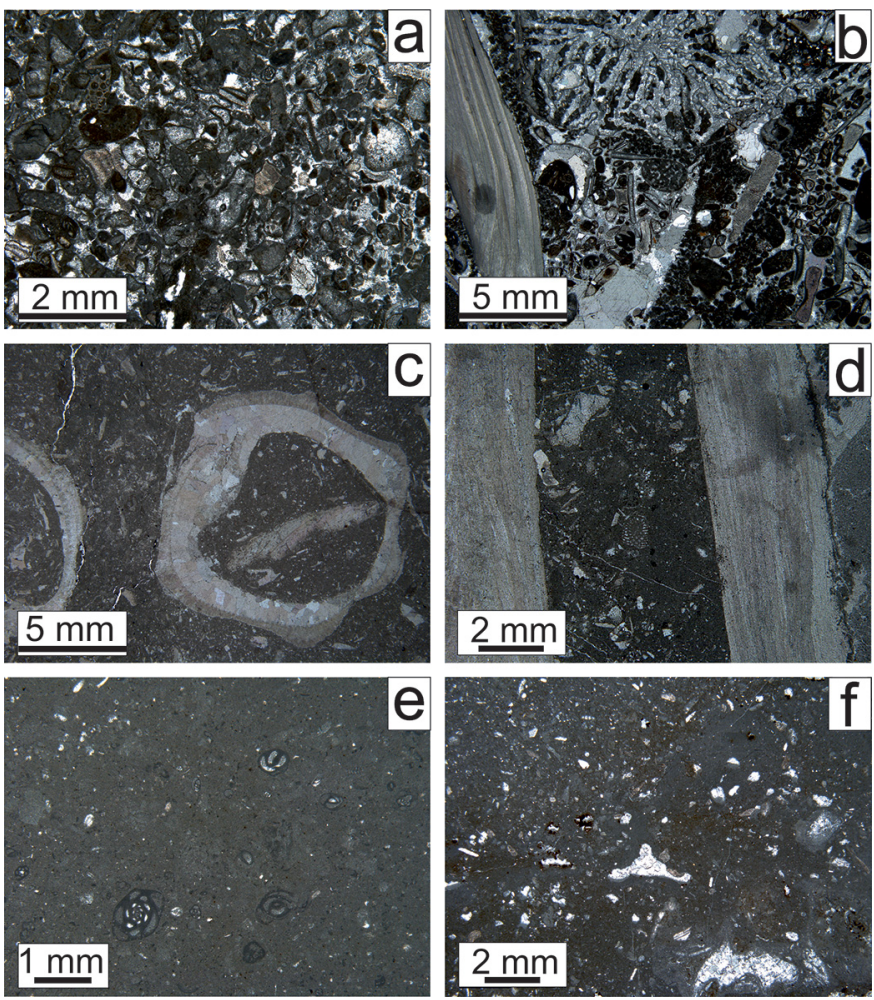

Fig. 14. Seguili Formation microfacies (see Fig. 13 for section details): a: fine-grained bioclastic-intraclastic grainstone with orbitoline fragments. Seguilí section, lower part of SF-1; b: coarse, poorly sorted bioclastic rudstone with corals, bivalves, peloids and intraclasts. Carrascal de Parcent section, lower-middle part of SF3; c: floatstone with rudists (Mathesia); matrix is wackestone with miliolids and small bioclasts. Carrascal de Parcent section, middle part of SF-2; d: floatstone with Chondrodonta; matrix is wackestone with Simplorbitolina and small bioclasts. Carrascal de Parcent section, upper part of SF-3; e: wackestone with miliolids. Seguilí section, upper part of SF-2; f: wackestone with micro-geopetal structures. Seguilí section, lower middle part of SF-2.

the most prominent macrofossils in the Seguili Formation are rudists, though with a strikingly altered cast with respect to the lower Aptian examples: thus, caprinids, previously so prominent, are now absent, while large requieniids (e.g., Pseudotoucasia santanderensis [Douvillé, 1889]; Figs. 16c and 16d) and polyconitids (Polyconites verneuili [Coquand, 1865; Fig. 16f]), as well as smaller radiolitids (e.g., Eoradiolites sp., Fig. 16g), all with appreciably thickened calcitic outer shell layers, accompany the remaining tubular monopleurid, Mathesia darderi (Astre, 1933) (Figs. 14c and 15c).

\section{Discussion}

In this section, we summarise similarities and contrasts between the Llopis and Seguilí Formations, as described above, especially with respect to their rudist associations (4.1). In 4.2, we draw parallels with co-eval examples from other parts of Iberia and contiguous regions and then briefly survey other Iberian platform successions that are intermediate in age between the two formations, during which time only hemipelagic deposits of the Almadich Formation were being deposited in the study area (Fig. 2), in order to gain a fuller picture of the changes in Iberian carbonate platforms during the Aptian. Finally, in 4.3, we discuss the possible causal factors that could have been involved in the macrofaunal turnover.

\subsection{Comparison of Aptian carbonate platforms in the Alicante region}

To a first approximation, carbonate platform progradation in the Llopis and Seguili Formations resulted in essentially the same biofacies anatomy: massive bioclastic slope deposits with largely transported rudists, corals and associated biota were succeeded by tabular platform-top beds, each up to a few metres thick and dominated by rudists - though with Chondrodonta also especially prominent locally, especially in the upper parts of the Seguilí Formation. In both cases, most of the platform-top beds show a repeated regressive cyclicity, each bed commencing with more or less dense floatstone containing parautochthonous to autochthonous rudist associations - comprising mainly elevators with some clingers - in a predominantly packstone matrix, passing up to a thin cover of much sparser floatstone with a miliolid-rich wackestone matrix. This cover facies may be penetrated by burrows secondarily filled by contrasting matrix and/or microkarstic deposits. Larger, thick-shelled rudists tend to dominate in the floatstones of the more external platform-top biofacies.

The main difference in detail between the two formations emerges from analysis of the taxonomic make-up of their rudist associations. Whereas diverse caprinids overwhelmingly dominate the outer platform-top facies of the Llopis Formation platform, they are entirely absent from the Seguilí Formation platform. On the other hand, radiolitids, which are absent from the Llopis Formation platform, are moderately common and widely distributed across the younger platform. Meanwhile, although clusters of the slender elevator monopleurid, Mathesia, together with polyconitids and requieniids, as well as the non-rudist bivalve Chondrodonta, are moderately common across the Llopis Formation platform-top, they are all relatively more abundant on the Seguili Formation platform, in which they also show increased mean shell size relative to their Llopis Formation predecessors - especially with the appearance of the large sediment-clinging requieniid Pseudotoucasia (Fig. 16c).

\subsection{Aptian carbonate platform development beyond the Alicante region}

The same overall pattern of biotic turnover from the Early to the Late Aptian has been documented in carbonate platforms in other parts of Iberia and contiguous regions (Masse, 1989; Masse et al., 1998; Skelton, 2000; Fenerci-Masse, 2006; Skelton and Gili, 2012). In the southern Lusitanian Basin of Portugal, for example, the outer platform-top facies of the Ponta Alta Member of the Crismina Formation, of earliest Aptian (early Bedoulian) age, contains abundant and diverse caprinids, (Skelton and Masse, 1998; Burla et al., 2008; Huck 


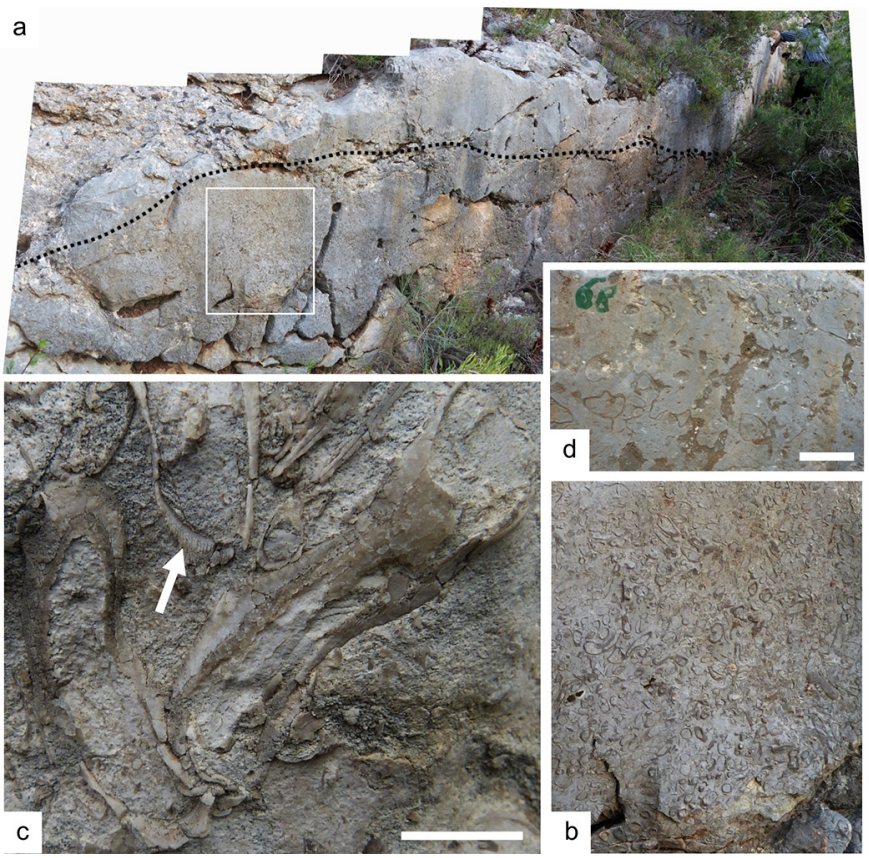

Fig. 15. Field photographs of platform-top bed in the Seguili Formation (upper part of SF-2) in the Sierra de Seguilí (see Fig. 13 for section details): a: panoramic view of vertical section of bed, with crest of Mathesia cluster outlined by dotted line; b: detail of autochthonous Mathesia cluster (= white rectangle in (a)); c: close-up view of mutually attached right valves of Mathesia darderi (Astre, 1933) preserved in life position (arrow indicates eroded section of diagnostic fine canals at inner margin of outer shell layer; see FenerciMasse et al., 2011); d: detail of wackestone at top part of bed (under man's hand at top right in (a)), with scattered large requieniids and burrows secondarily filled from above by orange-stained sediment. Scale bars: c: $10 \mathrm{~mm}$; $: 100 \mathrm{~mm}$.

et al., 2014), similar to those of the co-eval Llopis Formation. Meanwhile, though rudists are not mentioned from the coralbearing Umbrera Formation in the northern Spanish BasqueCantabrian Basin, García-Mondéjar et al. (2015a, 2015b) describe these shallow-water calcarenites as being overlain by ammonite-rich marly facies of the Patrocinio Formation, the first metres of which record the C3 to C6 segments of Menegatti et al. (1988). Thus, as with the Llopis Formation, the termination of the Umbrera Formation likewise predated the positive excursion phase of OAE1a. Although GarcíaMondéjar et al. (2015b, p. 8) caution that "There is no positive faunal evidence of a Deshayesites oglanlensis Zone age for the Umbrera Formation in the absence of ammonites", they note that "However, correlation of the geochemical data with the sections in Aralar, which contain ammonites of this age, support strongly an oglanlensis Zone age (García-Mondéjar et al., 2009)".

Further north, the distal platform-top facies of the "U2" Urgonian limestones in the North Provencal Platform likewise contains a rich and diverse caprinid fauna (Masse and FenerciMasse, 2011), while requieniids and monopleurids are distributed throughout the platform interior facies - though a recent revision of the ammonite biostratigraphy of that region re-assigns these U2 limestones to the Martelites sarasini
Subzone of latest Barremian, rather than earliest Bedoulian age (Frau et al., 2018).

On the other hand, platform deposits of Late Aptian (to earliest Albian) age, entirely lacking caprinids, but with large requieniids (especially Pseudotoucasia) and polyconitids, as well as monopleurids and radiolitids, have been recorded from numerous localities elsewhere in Iberia, for example from Portugalete (Bilbao), as described in the classic palaeontological account of Douvillé (1889), to the Maestrat Basin in NE Spain (Malchus, 1998), as well as in SE Spain, in relatively more proximal settings to the north and west of the present study area (Masse et al., 1998).

Of special interest in the present context, however, are Iberian platform successions of late Bedoulian age - hence intermediate in age between the Llopis and Seguilí Formations - that have been described from outside the present study area. These examples, particularly those situated within, or partly within the furcata Zone, reveal a transitional phase between the typical early Bedoulian (and/or latest Barremian), and the Late Aptian rudist faunas discussed above. Compared with the early Bedoulian examples, they show a significantly increased abundance of polyconitids in the outer platform-top to upper slope facies at the expense of caprinids, which, though still present, appear to have become more localized prior to their "Lazarus"-style disappearance at the close of the Bedoulian (Skelton and Gili, 2012). Again, examples may be cited from across northern Spain as well as in more proximal successions in south-eastern Spain.

In the Galve sub-basin of the western Maestrat Basin in northeastern Spain, for example, the marginal and upper slope facies of platform sequences within the Villarroya de los Pinares Formation are dominated by dense clusters of the founding species of Polyconites, P. hadriani, accompanied by corals (Bover-Arnal et al., 2010; Skelton et al., 2010; Gili et al., 2016). Caprinids, meanwhile, have a more localized and restricted distribution in the region (Bover-Arnal et al., 2015). A similar situation is encountered in the Basque-Cantabrian Basin in northern Spain (Aralar, Sarastarri Formation, Millán et al., 2009; Mount Pagasarri, Peñascal Formation, Fernández-Mendiola et al., 2017), where $P$. hadriani, and requieniids are again abundant, but caprinids limited to a few horizons within thick outer platform-top successions. In the carbonate platform succession of late Bedoulian age studied by Masse et al. $(1998 ; 2015)$ in more proximal parts of the Prebetic margin to the west of the study area, caprinid-bearing facies likewise are shown in their logs to be relatively limited in extent (e.g., in El Carche and Sierra Larga; Masse et al., 2015, fig. 2) - again accompanied by $P$. hadriani, which continues abundantly into the Gargasian.

To summarise, in Iberian carbonate platforms, caprinids, with largely aragonitic shells (having a calcitic outer shell layer of only sub-millimetric thickness; Skelton and Gili, 2012) dominated external platform-top rudist associations in the latest Barremian and early Bedoulian, but they were replaced by a consortium of large-shelled requieniids, polyconitids and radiolitids, together with Chondrodonta, all with relatively thicker (few to several $\mathrm{mm}$ ) calcitic outer shell layers, in the Late Aptian. This turnover was mediated in the late (especially latest) Bedoulian, by a phase of carbonate platform development in which caprinids, though still present, became more restricted in distribution, while polyconitids and requieniids, particularly, proliferated. 

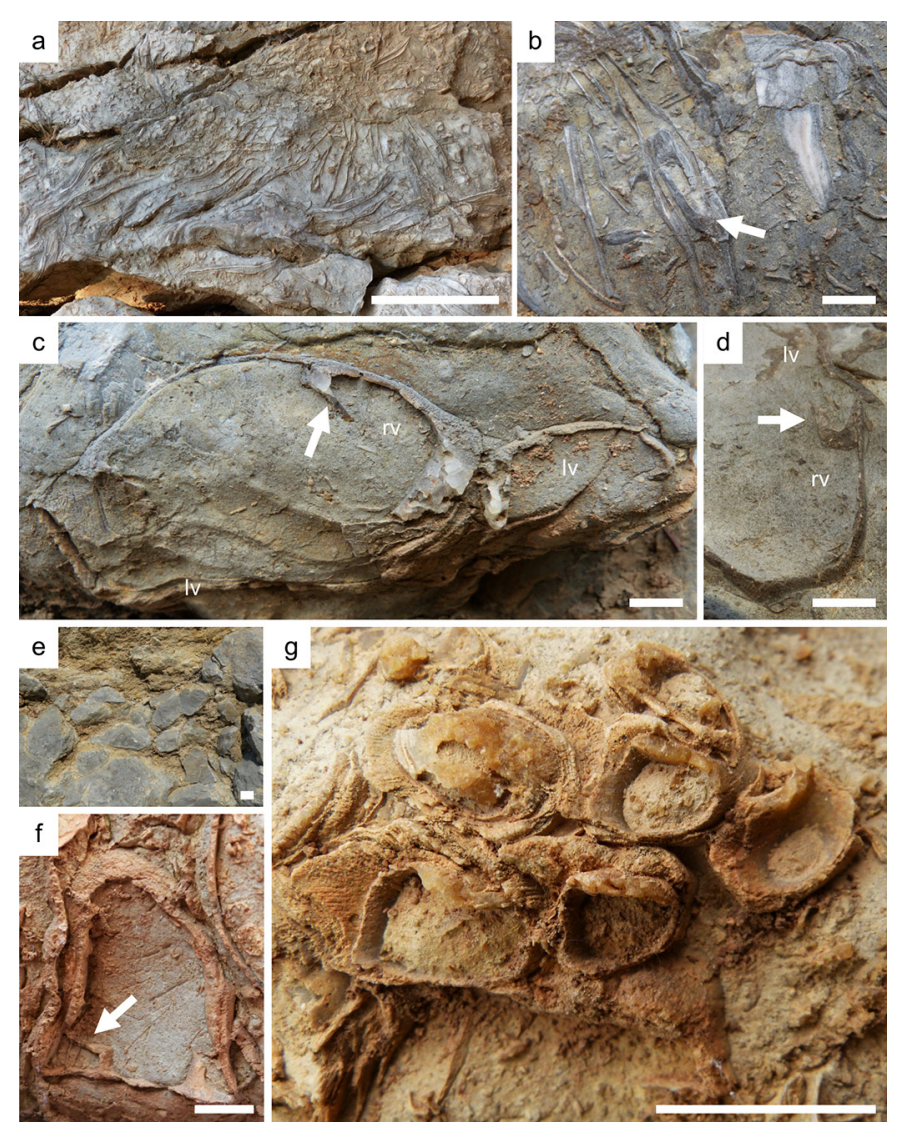

Fig. 16. Field photographs of platform-top facies and macrofauna in the upper part of the Seguilí Formation (SF-3), in the Barranco de Alcaida section (Carrascal de Parcent; see Fig. 2 for location and stratigraphical details): a: cluster of Chondrodonta shown in vertical section, preserved in inclined upright life position in bioclastic packstone matrix; b: close-up of vertical Chondrodonta, showing diagnostic under-folded chondrophore (arrowed); c: vertical section through attached left valve (lv), plus sliver of right valve (rv), including diagnostic posterior myophore (arrowed), of Pseudotoucasia santanderensis (Douvillé, 1889), preserved in life position in nodular marly bioclastic packstone in lower part of a cyclic bed; $d$ : detail from section across commissure of another specimen of $P$. santanderensis, showing posterior myophore in rv; e: vertical section through wackestone to sparse packstone top of a cyclic bed, with burrows secondarily filled with marl from base of overlying bed; $f$ : overturned articulated specimen of Polyconites verneuili (Coquand, 1865), with posterior myophore of right valve indicated by arrow, in bioclastic packstone matrix; g: small, overturned cluster of Eoradiolites sp., in bioclastic packstone matrix.

\subsection{Controls on platform-macrofaunal turnover}

The lower, and upper Bedoulian carbonate platform developments described above are stratigraphically distinct. The evidence relating to the demise of the Llopis Formation platform was detailed in the section on "Termination of the Llopis Formation Platform" (2.2). While regionally varying successions across the Llopis/Almadich boundary - including evidence for emersion in some places but not in others, as well as a locally additional sequence in the Mariola-Agres section
(Fig. 10) - indicate some tectonically induced differences in accommodation, the general correlation of the Llopis/ Almadich transition with the geochemical signature for the onset of OAE1a is remarkable. The siliciclastic influx locally preserved at the top of the otherwise carbonate-dominated succession of the Llopis Formation platform, moreover, suggests a climatic shift in this region from arid to relatively more humid/pluvial conditions in the late Bedoulian. A similar climatic change has been inferred for the same stratigraphical level in the southern Lusitanian Basin, and in the Algarve in Portugal (Burla et al., 2008; 2009), while Bover-Arnal et al., (2011) attributed a widespread horizon of storm-generated coral rubble beds in the Maestrat Basin, again correlative with the onset for OAE1a, to intensified greenhouse conditions with associated acceleration of the hydrological cycle. Such was the climatic context from which the late Bedoulian phase of platform recovery evidently took place, with the characteristic transitional rudist associations in Iberia cited above. Meanwhile, on some central to southern Tethyan platforms, by contrast, caprinids retained their dominance of outer platformtop environments through most if not all of the late Bedoulian most notably, for example, in the Shu'aiba Formation of eastern Arabia (Hughes, 2004; Skelton and Gili, 2012), succeeding the HST of the Hawar transgressive-regressive cycle, with which OAE1a is most likely correlatable (Granier and Busnardo, 2013). This broad palaeolatitudinal differentiation of rudist associations that is apparent within the Tethyan belt is strongly suggestive of a continuing climatic control, whether exerted through thermal modulation of seawater $\mathrm{pH}$ and/or aragonite saturation (the "kettle effect" of Skelton and Gili, 2012), variation in nutrient flux (Föllmi, 2012), or - perhaps most plausibly - a combination of these influences. That the distributions of individual Early Cretaceous rudist genera were indeed susceptible to climatic influence has already been demonstrated by Masse and Fenerci-Masse (2008).

Nevertheless, hypotheses that seek to link biotic turnover with global environmental changes rely crucially upon both sound stratigraphical correlation and adequate geographical sampling (Skelton et al., 2012). The recently revised dating by Frau et al. (2018) of the classic "U2" rudist limestones in the North Provencal Platform, from a previously supposed early Bedoulian age (Masse and Fenerci-Masse, 2011) to the latest Barremian, thus requires critical consideration. Even if this age re-assignment (based on the evidence of two ammonite specimens from the overlying "U3" limestones) is confirmed, together with rigorous verification of the total ranges of the two taxa concerned, Pseudocrioceras sp., and Martelites sp., there is no justification as yet for extrapolating this revised dating to the Iberian examples discussed in this paper. However, further testing of our current stratigraphical data, hence, our broader interpretation of events, should be pursued.

\section{Conclusions}

The Aptian stratigraphic record of the internal Prebetic zone in the Alicante region consists of three formations:

- the Llopis Formation, of earliest Aptian age, comprising shallow marine limestones with rudists and corals, locally with a thin siliciclastic member at its top; 
- the Almadich Formation, of late Early, to Late Aptian age, composed of ammonite-bearing hemipelagic marls and marlstones;

- the Seguilí Formation, of Late Aptian to earliest Albian age, with shallow marine limestones again containing rudists and corals. The Almadich Formation, records a longer time interval towards more distal, southern locations.

In the Llopis Formation, carbonate platform progradation is recorded by SW-dipping, massive clinoform beds of bioclastic debris that are succeeded by flat-lying platformtop beds. The latter show a cyclic stacking of biofacies, with rudist-dominated floatstone in their lower parts, including local clusters of slender elevator rudists preserved in upright life position, passing upwards to finer-grained, more sparsely fossiliferous bed tops, which may show burrow mottling. These beds are interpreted to represent minor regressive cycles. Similarly to other co-eval Tethyan platforms, caprinid rudists, with originally almost wholly aragonitic shells, dominate the external platform-top facies, while the relatively more internal facies contain a mix of monopleurid, polyconitid and requieniid rudists, all with relatively slightly thicker development of the calcitic outer shell layer, together with caprinids. Biostratigraphic and carbon-isotope data support a correlation between the termination of the Llopis platform and the onset of OAE1a, co-incident also with a pulse in extensional tectonics affecting the Southern Iberian Palaeomargin.

Building-out of the Seguilí Formation carbonate platform over the hemipelagic Almadich Formation took place in three steps (sequences), during the Late Aptian to earliest Albian. As in the Llopis Formation, tabular platform-top beds again show a pattern of repeated cyclic regression, involving dense rudist and/or chondrodont floatstones, with localized shell clusters preserved in life position, overlain by sparser floatstones with wackestone matrix and secondarily filled burrows. Although the most prominent macrofossils in the Seguilí Formation are, again, rudists, caprinids are now absent, while requieniids and polyconitids, some of large size, as well as radiolitids, all with appreciably thickened calcitic outer shell layers, accompany the remaining tubular monopleurid, Mathesia. The development of Chondrodonta biofacies is also notably greater than in the Llopis Formation.

The same overall pattern of biotic turnover from the Early to the Late Aptian has been documented for carbonate platforms in other parts of Iberia and contiguous regions. Additionally, Iberian platforms of late Early Aptian age outside the present study area - hence intermediate in age between the Llopis and Seguilí Formations - reveal a transitional phase between these successive rudist faunas. Compared to the earliest Aptian examples, they show an increasing abundance of polyconitids in the outer platform-top to upper slope facies at the expense of caprinids, which became more localized prior to their "Lazarus"-style disappearance at the close of the Early Aptian.

The siliciclastic influx locally preserved at the top of the Llopis Formation platform implies a climatic shift from arid to relatively more humid/pluvial conditions through the mid-Early Aptian, similar to that inferred for several other
Iberian sections. The co-incidence of this climatic change with the onset of OAE1a suggests that the former may be attributable to acceleration of the hydrological cycle forced by intensified greenhouse conditions. By contrast with the Iberian platforms, the outer platform-top zones of some central to southern Tethyan platforms remained dominated by caprinids until the close of the Early Aptian. This broad palaeolatitudinal differentiation of the turnover of rudist associations within the Tethyan belt is strongly suggestive of climatic influence, whether exerted through thermal modulation of seawater $\mathrm{pH}$ and/or aragonite saturation, variation in nutrient flux, or a combination of these.

Acknowledgements. This work is a contribution of the research project CGL2014-55274-P of the Spanish Ministry of Science and Technology, and Research Group RNM-200 (Junta de Andalucía). The Parque Natural Sierra de Mariola is acknowledged for the facilities and authorization to investigate in the protected area under their administration. The authors also wish to thank Miguel Company for the ammonite determinations, and A. Piedra for technical support in processing samples for thin-sections. We are very grateful to the referees, Jean-Pierre Masse and Kepa FernándezMendiola, whose constructive comments led to significant improvements in the final version of this paper, as did also the helpful editorial assistance of Danièle Grosheny. Finally, JMC wishes to acknowledge the kind contribution of Hubert and Annie Arnaud to his early career, introducing him to the methodology of Sequence Stratigraphy during a course held in Grenoble in 1992.

\section{References}

Aguado R, Castro JM, Company M, de Gea GA. 1999. Aptian bioevents-an integrated biostratigraphic analysis of the Almadich Formation, Inner Prebetic Domain, SE Spain. Cretaceous Research 20: 663-683.

Alonso-Chaves FM, Andreo B, Arias C, Azañón JM, Balanyá JC, Barón A, et al. 2004. Cordillera Bética y Baleares. In: Vera JA, ed. Geología de España. Madrid: Sociedad Geológica de España e Instituto Geológico y Minero de España, pp. 345-464.

Astre G. 1933. Sur les petits Agria tubuleux de l'Urgo-Aptien. Bulletin de la Société géologique de France 5: 99-105.

Bover-Arnal T, Moreno-Bedmar JA, Salas R, Skelton PW, Bitzer K, Gili E. 2010. Sedimentary evolution of an Aptian syn-rift carbonate system (Maestrat Basin, E Spain): Effects of accommodation and environmental change. Geologica Acta 8: 249-280.

Bover-Arnal T, Salas R, Martin-Closas C, Schlagintweit F, MorenoBedmar JA. 2011. Expression of an oceanic anoxic event in a neritic setting: Lower Aptian coral rubble deposits from the western Maestrat Basin (Iberian Chain, Spain). Palaios 26: 18-32.

Bover-Arnal T, Pascual-Cebrian E, Skelton PW, Gili E, Salas R, 2015. Patterns in the distribution of Aptian rudists and corals within a sequence-stratigraphic framework (Maestrat Basin, E Spain). Sedimentary Geology 321: 86-104.

Burla S, Heimhofer U, Hochuli PA, Weissert H, Skelton PW. 2008. Changes in sedimentary patterns of coastal and deep sea successions from the North Atlantic (Portugal) linked to Early Cretaceous environmental change. Palaeogeography, Palaeoclimatology, Palaeoecology 257: 38-57.

Burla S, Oberli F, Heimhofer U, Wiechert U, Weissert H. 2009. Improved time control on Cretaceous coastal deposits: New results 
from $\mathrm{Sr}$ isotope measurements using laser ablation. Terra Nova 21: 401-409.

Busnardo R, Champetier Y, Fourcade E, Moullade M. 1968. Etude stratigraphique des faciès à Orbitolinidés et à Rudistes de la Sierra Mariola (province d'Alicante, Espagne). Geobios 1: 165-185.

Castro JM. 1996. Aportaciones al conocimiento de la bioestratigrafía del tránsito Aptiense-Albiense en las Cordilleras Béticas, Prebético de Alicante. Geogaceta 20: 43-45.

Castro JM. 1998. Las plataformas del Valanginiense superiorAlbiense superior en el Prebético de Alicante. Granada: Tesis Doctoral, Universidad de Granada, 464 p.

Castro JM, Ruiz-Ortiz PA. 1995. Early Cretaceous evolution of the Prebetic Zone in the northeast Alicante province: The Sierra de Seguilí section. Cretaceous Research 16: 573-598.

Castro JM, Company M, de Gea GA, Aguado R. 2001. Biostratigraphy of the Aptian-Middle Cenomanian platform to basin domain in the Prebetic Zone of Alicante, SE Spain: Calibration between shallow water benthic and pelagic scales. Cretaceous Research 22: 145-156.

Castro JM, de Gea GA, Ruiz-Ortiz PA, Nieto LM. 2008. Development of carbonate platforms on an extensional (rifted) margin. The Valanginian-Albian record of the Prebetic of Alicante (SE Spain). Cretaceous Research 29: 848-860.

Castro JM, Jiménez de Cisneros C, de Gea GA, Ruiz-Ortiz PA, Quijano ML, Caballero E, et al. 2014. La Formación Almadich en la Sierra de Mariola: Caracterización litológica, bioestratigráfica, geoquímica y mineralógica (Aptiense inferior, Cordillera Bética, Alicante). Revista de la Sociedad Geológica de España 27: 27-136.

Charollais J, Clavel B, Busnardo R. 1994. Biostratigraphy and evolution of the urgonian platform from the Jura to the northern Subalpine Chains (SE France). Geologie Mediterraneénne 21: 35-38.

Chartrousse A. 1998. Les Caprinidae (Rudistes) du Crétacé inférieur. Marseille: PhD thesis, Université de Provence (Aix-Marseille I), Centre de Sédimentologie et Paléontologie, 281 p., 37 pl.

Clavel B, Conrad MA, Busnardo R, Charollais J, Granier B. 2013. Mapping the rise and demise of Urgonian platforms (Late Hauterivian-Early Aptian) in southeastern France and the Swiss Jura. Cretaceous Research 39: 29-46.

Company M, García-Hernández M, López-Garrido AC, Vera JA, Wilke H. 1982. Análisis y distribución de facies del Cretácico Inferior del Prebético en la provincia de Alicante. Cuadernos de Geología Ibérica 8: 563-578.

Coquand H. 1865. Monographie de l'étage Aptien de l'Espagne. Mémoires de la Société d'Emulation de la Provence, Marseille 5: 191-413.

de Gea GA, Castro JM, Aguado R, Company M, Ruiz-Ortiz PA. 2003. Lower Aptian carbon-isotope stratigraphy from a distal carbonate shelf setting. The Cau section, Prebetic Zone, SE of Spain. Palaeogeography, Palaeoclimatology, Palaeoecology 200: 207219.

Douvillé H. 1889. Sur quelques rudistes du terrain crétacé inférieur des Pyrénées. Bulletin de la Société géologique de France 17: 627-635.

Fenerci-Masse M. 2006. Les communautés à rudistes du Crétacé inférieur de la marge ouest Européenne de la Tethys. Marseille: Thèse de doctorat, Université de Provence, FRE-2761, 436 p.

Fenerci-Masse M, Masse J-P., Kołodziej B, Ivanov M, Idakieva V. 2011. Mathesia darderi (Astre) (Bivalvia, Hippuritoidea, Monopleuridae): Morphological, biogeographical and ecological changes in the Mediterranean domain during the late BarremianAlbian. Cretaceous Research 32: 407-421.
Fernández-Mendiola PA, Mendicoa J, Owen HG, García-Mondéjar J. 2017. The Early Aptian (Cretaceous) stratigraphy of Mount Pagasarri (N Spain): Oceanic anoxic event-1a. Geological Journal 2017:1-21. Available from https://doi.org/10.1002/gj.3008 (last consult: 2018/10/08).

Föllmi KB. 2012. Early Cretaceous life, climate and anoxia. Cretaceous Research 35: 230-257.

Frau C, Pictet A, Spangenberg JE, Masse J-P., Tendil AJ-B., Lanteaume C. 2017. New insights on the age of the post-Urgonian marly cover of the Apt region (Vaucluse, SE France) and its implications on the demise of the North Provence carbonate platform. Sedimentary Geology 359: 44-61.

Frau C, Tendil AJ-B., Lanteaume C, Masse J-P, Pictet A, Bulot LG, et al. 2018. Late Barremian-Early Aptian ammonite bioevents from the Urgonian-type series of Provence, southeast France: Regional stratigraphic correlations and implications for dating the periVocontian carbonate platforms. Cretaceous Research, Available from https://doi.org/10.1016/j.cretres.2018.04.008 (last consult: 2018/10/08).

García-Hernández M, Castro JM, Nieto LM. 2001. Los carbonatos del Cretácico Inferior del Prebético de la Sierra de Segura. In RuizOrtiz PA, Molina JM, Nieto LM, Castro JM, de Gea GA, eds. Itinerarios geológicos por el mesozoico de la provincia de Jaén. Jaén: Departamento de Geología, Universidad de Jaén, pp. 63-91.

García-Hernández M, Castro JM, Nieto LM. 2003. La transgresión Aptiense en la Sierra de Segura (Zona Prebética, provincia de Jaén). Geogaceta 33: 127-129.

García-Hernández M, López-Garrido AC, Rivas P, Sanz de Galdeano C, Vera JA. 1980. Mesozoic paleogeographic evolution of the external zones of the Betic Cordillera. Geologie en Mijnbouw 59: 155-168.

García-Mondéjar J, Fernández-Mendiola PA, Owen HG. 2015a. The OAE1a in Cuchía (Early Aptian, Spain): C and O geochemistry and global correlation. Acta Geológica Polonica 65: 525-543.

García-Mondéjar J, Owen HG, Fernández-Mendiola PA. 2015b. Early Aptian sedimentary record and OAE1a in Cuchía (northern Spain): New data on facies and ammonite dating. N. Jb. Geol. Paläont. Abh. 276 (1): 1-26.

García-Mondéjar J, Owen HG, Raisossadat N, Millán MI, FernándezMendiola PA. 2009. The Early Aptian of Aralar (northern Spain): Stratigraphy, sedimentology, ammonite biozonation, and OAE1a. Cretaceous Research 30: 434-464.

Gili E, Skelton PW, Bover-Arnal T, Salas R, Obrador A, FenerciMasse M. 2016. Depositional biofacies model for post-OAE1a Aptian carbonate platforms of the western Maestrat Basin (Iberian Chain, Spain). Palaeogeography, Palaeoclimatology, Palaeoecology 453: 101-114.

Gómez-Pérez I, Fernández-Mendiola PA, García-Mondéjar J. 1999. Depositional architecture of a rimmed carbonate platform (Albian, Gorbea, western Pyrenees). Sedimentology 46: 337-356.

Granier B, Busnardo R. 2013. New stratigraphic data on the Aptian of the Persian Gulf. Cretaceous Research 39: 170-182.

Hardenbol J, Thierry J, Farley MB, Jacquin T, de Graciansky PC, Vail PR. 1998. Mesozoic and Cenozoic sequence chronostratigraphic chart. In de Graciansky PC, Hardenbol J, Jacquin T, Vail PR, eds. Mesozoic and Cenozoic sequence stratigraphy of European basins. Tulsa: Society for Sedimentary Geology, Special Publication 60: Chart 1.

Hu X, Zhao K, Yilmaz IO, Li Y. 2012. Stratigraphic transition and palaeoenvironmental changes from the Aptian oceanic anoxic event 1a (OAE1a) to the oceanic red bed 1 (ORB1) in the Yenicesihlar section, central Turkey. Cretaceous Research 38: 40-51. 
Huck S, Heimhofer U, Rameil N, Bodin S, Immenhauser A. 2011. Strontium and carbon-isotope chronostratigraphy of BarremianAptian shoal-water carbonates: Northern Tethyan platform drowning predates OAE 1a. Earth and Planetary Science Letters 304: 547-558.

Huck S, Stein M, Immenhauser A, Skelton PW, Christ N, Föllmi KB, et al. 2014. Response of proto-North Atlantic carbonate-platform ecosystems to OAE1a-related stressors. Sedimentary Geology 313: $15-31$.

Hughes GW. 2004. Palaeoenvironments of selected Lower Aptian rudists from Saudi Arabia. Cour. Forsch. -Inst.Senckenberg 247: 233-245.

Jenkyns HC. 2018. Transient cooling episodes during Cretaceous Oceanic Anoxic Events with special reference to OAE1a (Early Aptian). Phil. Trans. R. Soc. A 376: 20170073. Available from http://dx.doi.org/10.1098/rsta.2017.0073 (last consult: 2018/ 12/09).

Kollmann HA. 2014. The extinct Nerineoidea and Acteonelloidea (Heterobranchia, Gastropoda): A palaeobiological approach. Geodiversitas 36: 349-383.

Li Y-X., Bralower TJ, Montañez IP, Osleger DA, Arthur MA, Bice DM, et al. 2008. Toward an orbital chronology for the early Aptian Oceanic Anoxic Event (OAE1a, 120Ma). Earth and Planetary Science Letters 271: 88-100.

Lorenzen J, Kuhnt W, Holbourn A, Flögel S, Moullade M, Tronchetti G. 2013. A new sediment core from the Bedoulian (Lower Aptian) stratotype at Roquefort-La Bédoule, SE France. Cretaceous Research 39: 6-16.

Mainelli M. 1983. Nuove Rudiste del Cretacico inferior-medio di Monte La Costa (S. Polo Matese, Campobasso). Bollettino della Società Paleontologica Italiana 22: 189-208.

Malchus N. 1998. Aptian (Lower Cretaceous) rudist bivalves from NE Spain: Taxonomic problems and preliminary results. Geobios, Mémoire Spécial 22: 181-191.

Malinverno A, Erba E, Herbert TD. 2010. Orbital tuning as an inverse problem: Chronology of the early Aptian oceanic anoxic event 1a (Selli Level) in the Cismon APTICORE. Paleoceanography 25, PA 2203, 16 p. doi:10.1029/2009PA001769.

Martín-Chivelet J, Berasategui X, Rosales I, Vilas L, Vera JA, Caus E, et al. 2002. Cretaceous. In Gibbons W, Moreno T, eds. The Geology of Spain. London: Geological Society, pp. 255-292.

Martínez-Rodríguez R, Castro JM, de Gea GA, Nieto LM, Reolid M, Ruiz-Ortiz PA. 2018 (in press). Facies analysis and stratigraphy of a lower Aptian Carbonate Platform section (Prebetic, Alicante, Spain). Geogaceta 64.

Masse J-P. 1989. Relations entre modifications biologiques et phénomènes géologiques sur les plates-formes carbonatées du domaine périméditerranéen au passage Bédoulien-Gargasien. Geobios, Mémoire Spécial 11: 279-294.

Masse J-P., Chartrousse A. 1997. Les Caprina (rudistes) de l'Aptien inférieur d'Europe occidentale: Systématique, biostratigraphie et paléobiogéographie. Geobios 30: 797-809.

Masse J-P., Fenerci-Masse M. 2008. Time contrasting palaeobiogeographies among Hauterivian-Lower Aptian rudist bivalves from the Mediterranean Tethys, their climatic control and palaeoecological implications. Palaeogeography, Palaeoclimatology, Palaeoecology 269: 54-65.

Masse J-P., Fenerci-Masse M. 2009. Debrunia, a new Barremian genus of petalodontid Monopleuridae (Bivalvia, Hippuritoidea) from the Mediterranean region. Palaeontology 52: 1363-1372.

Masse J-P., Fenerci-Masse M. 2010. Mathesia Mainelli (Hippuritoidea, Monopleuridae) from the Late-Aptian-Albian of the
Mediterranean Region: A revision. Turkish Journal of Earth Sciences 19: 543-556.

Masse J-P, Fenerci-Masse M. 2011. Drowning discontinuities and stratigraphic correlation in platform carbonates. The late Barremian-early Aptian record of southeast France. Cretaceous Research 32: 659-684.

Masse J-P., Fenerci-Masse M. 2013a. Drowning events, development and demise of carbonate platforms and controlling factors: The Late Barremian-Early Aptian record of Southeast France. Sedimentary Geology 298: 28-52.

Masse J-P, Fenerci-Masse M. 2013b. Stratigraphic updating and correlation of Late Barremian-Early Aptian Urgonian successions and their marly cover, in their type region (Orgon-Apt, SE France). Cretaceous Research 39: 17-28.

Masse J-P., Fenerci-Masse M. 2017. Taxonomy and stratigraphy of late Barremian-Albian species of Horiopleura Douvillé (Hippuritida, Polyconitidae) of the Mediterranean and southwestern Asian regions. Cretaceous Research 76: 53-80.

Masse J-P., Arias C, Vilas L. 1998. Lower Cretaceous rudist faunas of southeast Spain: An overview. Geobios, Mémoire Spécial 22: $193-210$

Masse J-P, Fenerci-Masse M, Arias C, Vilas L. 2015. Description of a new species of Offneria (Hippuritida, Caprinidae) from the lower Aptian of southeast Spain. Stratigraphic, evolutionary, palaeobiogeographic and palaeoenvironmental implications. Cretaceous Research 53: 153-166.

Menegatti AP, Weissert H, Brown RS, Tyson RV, Farrimond P, Strasser A, et al. 1998. High-resolution ä13C stratigraphy through the Early Aptian "Livello Selli" of the Alpine Tethys. Paleoceanography 13: 530-545.

Millán MI, Weissert HJ, López-Horgue M. 2014. Expression of the late Aptian cold snaps and the OAE1b in a highly subsiding carbonate platform (Aralar, northern Spain). Palaeogeography, Palaeoclimatology, Palaeoecology 411: 167-179.

Millán MI, Weissert HJ, Fernández-Mendiola PA, García-Mondéjar J. 2009. Impact of Early Aptian carbon cycle perturbations on evolution of a marine shelf system in the Basque-Cantabrian Basin (Aralar, N Spain), Earth and Planetary Science Letters 287: 392-401.

Moreno-Bedmar JA, Barragán R, Delanoy G, Company M, Salas R. 2014. Review of the early Aptian (Early Cretaceous) ammonoid species Deshayesites deshayesi (d'Orbigny, 1841). Cretaceous Research 51: 341-360.

Moreno-Bedmar JA, Company M, Bover-Arnal T, Salas R, Delanoy G, Martínez R, et al. 2009. Biostratigraphic characterization by means of ammonoids of the lower Aptian Oceanic Anoxic Event (OAE 1a) in the eastern Iberian Chain (Maestrat Basin, eastern Spain). Cretaceous Research 30: 864-872.

Moreno-Bedmar JA, Company M, Sandoval J, Tavera JM, BoverArnal T, Salas R, et al. 2012. Lower Aptian ammonite and carbon isotope stratigraphy in the eastern Prebetic Domain (Betic Cordillera, southeastern Spain). Geologica Acta 10: 333-350.

Naafs BDA, Castro JM, de Gea GA, Quijano ML, Schmidt DN, Pancost RD. 2016. Gradual and sustained carbon dioxide release during Aptian Oceanic Anoxic Event 1a. Nature Geoscience 9: 135-139.

Najarro M, Rosales I, Martín-Chivelet J. 2011. Major palaeoenvironmental perturbation in an Early Aptian carbonate platform: Prelude of the Oceanic Anoxic Event 1a? Sedimentary Geology 235: 50-71.

Olivet JM. 1996. La cinématique de la plaque ibérique. Bulletin des centres de recherches exploration-production Elf-Aquitaine 20: 131-195. 
Paquier V. 1905. Les rudistes urgoniens. II. Série inverse. Mémoires de la Société géologique de France. Paléontologie 29(13): 47-102.

Pictet FJ, Campiche G. 1869. Description des fossiles du terrain Crétacé de Sainte-Croix. Matériaux pour la paléontologie suisse 9 (5): 1-352.

Posenato R, Morsilli M, Guerzoni S, Bassi D. 2018. Palaeoecology of Chondrodonta (Bivalvia) from the lower Aptian (Cretaceous) Apulia Carbonate Platform (Gargano Promontory, southern Italy). Palaeogeography, Palaeoclimatology, Palaeoecology 508: 188-201.

Reboulet S, Rawson PF, Moreno-Bedmar JA, Aguirre-Urreta MB, Barragán R, Bogomolov Y, et al. 2011. Report on the 4th International Meeting of the IUGS Lower Cretaceous Ammonite Working Group, the "Kilian Group" (Dijon, France, 30th August 2010), Cretaceous Research 32: 786-793.

Reboulet S, Szives O, Aguirre-Urreta B, Barragán R, Company M, Idakieva V, et al. 2014. Report on the 5th International Meeting of the IUGS Lower Cretaceous Ammonite Working Group, the Kilian Group (Ankara, Turkey, 31st August 2013). Cretaceous Research 50: 126-137.

Ruiz-Ortiz PA, Castro JM. 1998. Carbonate depositional sequences in shallow to pelagic platform deposits. Aptian. Prebetic of Alicante (SE Spain). Bulletin de la Société géologique de France 169: 21-33.

Ruiz-Ortiz PA, Castro JM, de Gea GA, Jarvis I, Molina JM, Nieto LM, et al. 2016. New drilling of the early Aptian OAE1a: The Cau core (Prebetic Zone, south-eastern Spain). Scientific Drilling 21: $41-46$.

Skelton PW. 2000. Rudists and carbonate platforms-growing together, dying together. In Cherchi A, Corradini C, eds. Crisi biologiche, radiazioni adattative e dinamica delle piattaforme carbonatiche. Accad. Naz. Sci. Lett. Arti di Modena, Collana di Studi 21: 231-235.

Skelton PW, Masse J-P. 1998. Revision of the Lower Cretaceous rudist genera Pachytraga Paquier and Retha Cox (Bivalvia: Hippuritacea), and the origins of the Caprinidae. Geobios, Mémoire Spécial 22: 331-370.

Skelton PW, Gili E. 2012. Rudists and carbonate platforms in the Aptian: A case study on biotic interactions with ocean chemistry and climate. Sedimentology 59: 81-117.
Skelton PW, Granier B, Moullade M. 2012. Introduction to thematic issue, "Spatial patterns of change in Aptian carbonate platforms and related events". Cretaceous Research 39: 1-5.

Skelton PW, Gili E, Rosen BR, Valldeperas FX. 1997. Corals and rudists in the late Cretaceous: A critique of the hypothesis of competitive displacement. Boletín de la Real Sociedad Española de Historia Natural-(Sección Geológica) 92: 225-239.

Skelton PW, Gili E, Bover-Arnal T, Salas R, Moreno-Bedmar JA. 2010. A new species of Polyconites from the Lower Aptian of Iberia and the early evolution of polyconitid rudists. Turkish Journal of Earth Sciences 19: 557-572.

Tugend J, Manatschal G, Kusznir NK. 2015. Spatial and temporal evolution of hyperextended rift systems: Implication for the nature, kinematics, and timing of the Iberian-European plate boundary. Geology 43: 15-18. Doi:10.1130/G36072.1

Vera JA. 2001. Evolution of the Southern Iberian Continental Margin. In Ziegler PA, Cavazza W, Robertson AHF, Crasquin-Soleau S, eds. Peri-Tethyan Rift/ Wrench Basins and Passive Margins. Paris: Mémoires du Muséum National d'Histoire Naturale 186: 109-143.

Vera JA, ed. 2004. Geología de España. Madrid: Sociedad Geológica de España e Instituto Geológico y Minero de España, 890p.

Vergès J, García-Senz J. 2001. Mesozoic evolution and Cainozoic inversion of the Pyrenean Rift. In Ziegler PA, Cavazza W, Robertson AHF, Crasquin-Soleau J, eds. Peri-Tethys Memoir 6: Peri-Tethyan Rift/Wrench Basins and Passive Margins. Paris: Mémoires du Muséum National d'Historie Naturelle 186: $187-212$.

Vilas L, Masse J-P, Arias C. 1993. Aptian mixed terrigenous and carbonate platforms from Iberic and Prebetic regions, In Simo JA, Scott RW, Masse J-P, eds. Cretaceous carbonate platforms. Tulsa: American Association of Petroleum Geologists, Memoir 56: 243-253.

Vilas L, Dabrio CJ, Peláez JR, García-Hernández M. 2001. Dominios sedimentarios generados durante el período extensional Cretácico Inferior entre Cazorla y Hellín (Béticas Externas). Su implicación en la estructura actual. Revista de la Sociedad Geológica de España 14: $113-122$.

Ziegler PA. 1988. Evolution of the Artic-North Atlantic and the Western Tethys, publ. Int. lithos. Program, 0144. Tulsa: American Association of Petroleum Geologists, Memoir Memoir 43, 193p.

Cite this article as: Skelton PW, Castro JM, Ruiz-Ortiz PA. 2019. Aptian carbonate platform development in the Southern Iberian Palaeomargin (Prebetic of Alicante, SE Spain), BSGF - Earth Sciences Bulletin 190: 3. 